\title{
JURIDICAL STATUS OF SO-CALLED SMART CONTRACTS AGAINST THE BACKGROUND OF THE POLISH LEGAL FRAMEWORK*
}

\author{
by
}

BOGNA KACZOROWSKA*

\begin{abstract}
Among substantial advancements challenging contemporary contract law special attention is given to autonomous, cryptographic solutions based on decentralised infrastructure provided by blockchain technology, intended to execute transactions automatically, designated as smart contracts. The need for comprehensive research on legal implications of practical implementation of this technological innovation is triggered particularly by the prognostications declaring it a valid alternative to hitherto contract law framework that is expected to be ultimately replaced by algorithmic mechanisms underpinning smart contracts.

A relevant assessment of the impact smart contracts are presumed to have on the contract law domain requires a thorough analysis of their juridical status. The specificity of the category of smart contracts raises doubts whether they comply with the definition criteria inherent to contract law terminology. Additionally, it is of material importance to determine the function smart contracts can perform in the sphere of contractual practice and to confront it with the role and axiology of contract law.
\end{abstract}

The article aims at analysing the peculiarities of smart contracts from the perspective of the Polish private law system with account being also taken of current development tendencies concerning the concept of contract.

The article constitutes an extended version of the paper delivered at 16th International Conference Cyberspace held in Brno, 30 November - 1 December 2018.

* bogna.Kaczorowska@uwr.edu.pl, Department of Civil Law and Private International Law, Institute of Civil Law, Faculty of Law, Administration and Economics, University of Wrocław, Poland. 


\section{KEY WORDS}

Algorithmisation, Blockchain-based "Smart Contracts", Concept of Contract, Contract Law, Contractual Obligations, Polish Private Law

\section{INTRODUCTION}

The current phase of development in the sphere of digital technologies brings multifarious implications which private law framework needs to be confronted with. ${ }^{1}$ Intricate questions being raised for consideration in the context of unprecedented progress mainly in digitisation and automation processes induce to verify whether the essential private law institutions remain appropriate and functional. ${ }^{2}$ This refers in particular to the domain of contract law ${ }^{3}$ deemed notably exposed to novel tendencies regarding innovative patterns of arranging and conducting economic exchange. ${ }^{4}$ Among substantial advancements challenging contemporary contract law special attention is given to autonomous cryptographic solutions based on decentralised infrastructure provided by blockchain technology, intended to execute and enforce transactions automatically, designated as smart contracts. ${ }^{5}$ The need for comprehensive research on legal ramifications resulting from practical implementation of this technological innovation is triggered particularly by the prognostications declaring it a valid alternative to hitherto contract law framework that is expected to be ultimately replaced by algorithmic mechanisms underpinning smart contracts. ${ }^{6}$

A relevant assessment of the impact smart contracts are presumed to have on contract law requires a thorough analysis of their juridical status. The specificity of the category of smart contracts raises doubts whether they

Cf. Machnikowski, P. (2015b) Prawo zobowiązań w 2025 roku. Nowe technologie, nowe wyzwania. In: A. Olejniczak et al. (eds.). Współczesne problemy prawa zobowiazań. Warszawa: Lex a Wolters Kluwer Business, pp. 379 et seq.; Kurosz, K. (2017) Zawieranie umów przez sztuczną inteligencję (systemy autonomiczne) a wady oświadczeń woli- wprowadzenie do problemu. In: W. Robaczyński (ed.). Czynić postęp w prawie. Księga jubileuszowa dedykowana Profesor Birucie Lewaszkiewicz-Petrykowskiej. Łódź: Wydawnictwo Uniwersytetu Łódzkiego, pp. 73 et seq.; Sellwood, M. (2017) The Road to Autonomy. San Diego Law Review, 54 (4), pp. 830 et seq.; Grundmann, S. and Hacker, P. (2017) Digital Technology as a Challenge to European Contract Law: From the Existing to the Future Architecture. European Review of Contract Law, 13 (3), pp. 255-293.

2 Cf. i.a.: Kocot, W.J. (2017) Kontrakty kreatywne - nowy rozdział w cyberewolucji prawa umów. In: P. Kostański, P. Podrecki and T. Targosz (eds.). Experientia docet. Księga jubileuszowa ofiarowana Pani Profesor Elżbiecie Traple. Warszawa: Wolters Kluwer, pp. 946 et seq.; Schulze, R. and Staudenmayer, D. (2016) Digital Revolution - Challenges for Contract Law. In: R. Schulze and D. Staudenmayer (eds.). Digital Revolution: Challenges for Contract Law in Practice. Baden-Baden: Nomos, pp. 19 et seq.; Geis, G.S. (2008) Automating Contract Law. New York University Law Review, 83 (2), pp. 450-500. 
comply with the definition criteria inherent to contract law terminology. Additionally, it is of material importance to determine the function smart contracts can perform in the sphere of contractual practice and to confront it with the role and axiology of contract law considering also current development tendencies concerning the concept of contract.

Without pretending to explore the question conclusively, the analysis will cover selected issues regarding the properties of smart contracts in the light of Polish private law with a view toward delineating debatable aspects that shall affect qualification of this technological innovation in legal terms.

\section{DEFINITIONAL ASSUMPTIONS AND TERMINOLOGICAL QUERY ABOUT SMART CONTRACTS}

In respect of smart contracts' technological peculiarities to be juxtaposed with private law institutions, it is argued that a distinctive hindrance to comprehensive analysis thereof consists in terminological inappropriateness and misapplication of conceptual framework

3 It should be noted that due to the structure of Polish private law conforming with pandectistic system in which a central position is attributed to a general category of juridical acts, contract law is not formally recognised as a separate area. Nevertheless, on account of unquestionable relevance of contracts in the practice of legal interactions, one is not precluded from analysing the complex body of private law norms regarding different aspects of contracts and contractual obligations (despite their dispersal amongst provisions included in the general part of civil law and the law of obligations) as an integral whole to be referred to as contract law. Cf. Machnikowski, P. (2010) Prawne instrumenty ochrony zaufania przy zawieraniu umowy. Wrocław: Wydawnictwo Uniwersytetu Wrocławskiego, pp. 12-13; Machnikowski, P., Balcarczyk, J. and Drela, M. (2017) Contract Law in Poland. Alphen aan den Rijn: Kluwer Law International, pp. 25, 29, 42; Łolik, M. (2014) Wspótczesne prawo kontraktów - wybrane zagadnienia. Warszawa: Wydawnictwo C.H. Beck, p. 1; Romanowski, M. (2013) Position of the Law of Obligations in Polish Law in the Context of a Reform of the European Law of Obligations. In: R. Schulze and F. Zoll (eds.). The Law of Obligations in Europe: A New Wave of Codifications. Munich: Sellier European Law Publishers, pp. 67-69; Brzozowski, A. (2013) Pojęcie umowy w prawie polskim, funkcje umów. Źródła prawa regulującego umowy. In: System prawa prywatnego. 5: E. Łętowska (ed.). Prawo zobowiazań- czéść ogólna. Warszawa: Wydawnictwo C.H. Beck, p. 421. On the evolution of Polish contract law, see also: Konopacka, M. (2017) Kamienie milowe w rozwoju historycznym polskiego prawa umów. Gdańskie Studia Prawnicze, 38 (2), pp. 309-320. It shall be emphasised that the current Polish contract law is largely based on no longer in force legal solutions adopted in the Decree of the President of the Republic of Poland of 27 October 1933 - Code of Obligations (rozporządzenie Prezydenta Rzeczypospolitej - Kodeks zobowiązań, Journal of Laws No. 82, item 598, as amended, hereinafter: the Code of Obligations), commonly perceived as "the first genuinely European civil law codification" and "the most prominent achievement of the interwar European private law doctrine" (see i.a.: Dajczak, W. (2014) Kodeks zobowiązań jako lekcja metody prawnoporównawczej. Kwartalnik Prawa Prywatnego, 4, pp. 829, 852-853; Giaro, T. (2013) Some Prejudices about the Legal Tradition of Eastern Europe. In: B. Sitek, J.J. Szczerbowski and A.W. Bauknecht (eds.). Comparative Law in Eastern and Central Europe. Newcastle upon Tyne: Cambridge Scholars Publishing, pp. 42-43).

4 Cf. i.a.: Łolik, M. (2014) Op. cit., p. 3. 
appertaining to contract law. ${ }^{7}$ The category of smart contracts is defined ${ }^{8}$ essentially $^{9}$ by reference to a type of computer programmes operating autonomously on distributed, decentralised database secured cryptographically, denominated as blockchain, enabling automatic and irrevocable performance and execution of transactions, once the predefined conditions are met. ${ }^{10}$ Purportedly, blockchain technology underlying smart contracts provides a mechanism of recording any transaction performed on the network and distributing a copy of it among single nodes involved upon prior consensus in verification ("validation") procedure, without the need for recourse to trusted institutional intermediaries. ${ }^{11}$ One should, however, take account of avowed diversity of smart contracts and

Cf. Caria, R. de. (2018) The Legal Meaning of Smart Contracts. European Review of Private Law, 26 (6), pp. 731-751; Allen, J.G. (2018) Wrapped and Stacked: 'Smart Contracts' and the Interaction of Natural and Formal Language. European Review of Contract Law, 14 (4), pp. 307-343; Werbach, K. (2018) Trust, but Verify: Why the Blockchain Needs the Law. Berkeley Technology Law Journal, 33 (2), pp. 493, 504 et seq.; Millard, C. (2018) Blockchain and Law: Incompatible Codes? Computer Law E Security Review, 34 (4), pp. 843-846; Szostek, D. (2018) Blockchain a prawo. Warszawa: Wydawnictwo C.H. Beck, pp. 27 et seq., 113 et seq.; Szczerbowski, J.J. (2018a) Lex cryptographia. Znaczenie prawne umów i jednostek rozliczeniowych opartych na technologii blockchain. Warszawa: Wydawnictwo Naukowe PWN, pp. 11 et seq.; Bacina, M. (2018) When Two Worlds Collide: Smart Contracts and the Australian Legal System. Journal of Internet Law, 21 (8), pp. 1, 16 et seq.; Reyes, C.L. (2018) Cryptolaw for Distributed Ledger Technologies: A Jurisprudential Framework. Jurimetrics: The Journal of Law, Science E Technology, 58 (3), pp. 283-302; Goldenfein, J. and Leiter, A. (2018) Legal Engineering on the Blockchain: 'Smart Contracts' as Legal Conduct. Law and Critique, 29 (2), pp. 141 et seq.; Idelberger, F. (2018) Connected Contracts Reloaded - Smart Contracts as Contractual Networks. In: S. Grundmann (ed.). European Contract Law in the Digital Age. Cambridge-Antwerp-Portland: Intersentia, pp. 205 et seq.; Hsiao, J.I.-H. (2017) Smart Contract on the Blockchain - Paradigm Shift for Contract Law?. US-China Law Review, 14 (10), pp. 685-694; Giancaspro, M. (2017) Is a 'Smart Contract' Really a Smart Idea?: Insights from a Legal Perspective. Computer Law E Security Review, 33 (6), pp. 825-835; Malby, S. (2017) Strengthening the Rule of Law through Technology. Commonwealth Law Bulletin, 43 (3-4), pp. 314, 316-317; Wheeler, S. (2017) Visions of Contract. Journal of Law and Society, 44 (S1), pp. S76, S90-S91; Raskin, M. (2017) The Law and Legality of Smart Contracts. Georgetown Law Technology Review, 1 (2), pp. 306 et seq. Institutional initiatives towards exploring prospects for widespread use of blockchain-based applications (including smart contracts) in the field of digitised transactions, comprising also analytical work on an adequate regulatory surroundings, have been undertaken in Poland within the framework of governmental strategy. On the activities devoted to blockchain technology under operational programme "Od papierowej do cyfrowej Polski" ("From Paper to Digital Poland", "Paperless\&Cashless Poland") coordinated and supervised by the Ministry of Digital Affairs as a part of the governmental policy "Plan na rzecz odpowiedzialnego rozwoju" ("Action plan for responsible development of Poland") adopted upon the resolution No. 14/2016 of the Council of Ministers of 16 February $2016 \mathrm{cf}$. also i.a.: Hulicki, M. and Lustofin, P. (2017) Wykorzystanie koncepcji blockchain w realizacji zobowiązań umownych. Człowiek w Cyberprzestrzeni, 1, pp. 42-43; Szostek, D. (2018) Op. cit., pp. 1, 4-5. In order to critically identify the fields in which implementation of blockchain technology brings real benefits when compared with other technical solutions, in December 2018 the Ministry of Digital Affairs has established the Working Group on Distributed Ledgers and Blockchain whose activity falls within the scope of the Distributed Ledgers Stream created upon the decision of the Chairman of the Council of Ministers Committee for Digital Affairs of 10 October 2018. See: Ministerstwo Cyfryzacji. (2019) Grupa robocza ds. rejestrów rozproszonych $i$ blockchain. [online] Available from: https://www.gov.pl/web/cyfryzacja/ grupa-robocza-ds-rejestrow-rozproszonych-i-blockchain1 [Accessed 7 August 2019]. 
multiplicity of blockchains' structures as well as manifold configurations in which particular smart contracts can act upon respective blockchains. ${ }^{12}$ Accordingly, due to conspicuous heterogeneity of smart contracts forms it is necessary to emphasise that actually only some of them can be ultimately examined in terms of congruence with legal constructs and, where appropriate, equated with contracts in juridical sense. ${ }^{13}$ In this context, the very denomination granted to smart contracts requires a critical analysis. Above all, anticipating further study and without losing sight of the complexity of contract definition in different legal traditions, ${ }^{14}$ it should be stated that in case of the designation under consideration the reference to the concept of contract appears to be rather a hyperbole. ${ }^{15}$ It seems symptomatic that smart contracts tend to be characterised in terms

6 Cf. Savelyev, A. (2017) Contract Law 2.0: 'Smart' Contracts as the Beginning of the End of Classic Contract Law. Information \& Communications Technology Law, 26 (2), pp. 116-134. In this context, including polemical remarks, see also: Durovic, M. and Janssen, A. (2018) The Formation of Blockchain-Based Smart Contracts in the Light of Contract Law. European Review of Private Law, 26 (6), pp. 754 et seq.; Szczerbowski, J.J. (2018a) Op. cit., pp. 12 et seq., 54-55; Cannarsa, M. (2018) Interpretation of Contracts and Smart Contracts: Smart Interpretation or Interpretation of Smart Contracts?. European Review of Private Law, 26 (6), pp. 775 et seq.; Sklaroff, J.M. (2017) Smart Contracts and the Cost of Inflexibility. University of Pennsylvania Law Review, 166 (1), pp. 265 et seq.

7 Mik, E. (2017) Smart Contracts: Terminology, Technical Limitations and Real World Complexity. Law, Innovation and Technology, 9(2), pp. 270, 272 et seq.; Mik, E. (2018) Electronic Platforms: Openness, Transparency \& Privacy Issues. European Review of Private Law, 26 (6), pp. 855, 856, 867 et seq.; Szostek, D. (2018) Op. cit., p. 114 et seq.; Durovic, M. and Janssen, A. (2018) Op. cit., pp. 755 et seq.

8 One shall consider both doctrinal attempts to conceptualise smart contracts and increasing number of enactments covering the concept of smart contracts. For an overview of recently adopted legal definitions of smart contracts, see i.a.: Pardolesi, R. and Davola, A. (2019) "Smart contract": lusinghe ed equivoci dell'innovazione purchesia. In: F. Capriglione (ed.). Liber Amicorum Guido Alpa. Milano: Cedam, pp. 297-316; Rohr, J. (2019) Smart Contracts in Traditional Contract Law, Or: The Law of the Vending Machine. Cleveland State Law Review, 67 (1), pp. 71 et seq.; Temte, M.N. (2019) Blockchain Challenges Traditional Contract Law: Just How Smart Are Smart Contracts?. Wyoming Law Review, 19 (1), pp. 88 et seq.; Caria, R. de. (2018) Op. cit., pp. 735-737 et seq.; DiMatteo, L.A. and Poncibò, C. (2018) Quandary of Smart Contracts and Remedies: The Role of Contract Law and Self-Help Remedies. European Review of Private Law, 26 (6), p. 806; Szostek, D. (2018) Op. cit., pp. 119-120; Szczerbowski, J.J. (2018a) Op. cit., p. 18; Ridder, C.A. de, Tunstall, M.K. and Prescott, N. (2017) Recognition of Smart Contracts in the United States. Intellectual Property E Technology Law Journal, 29 (11), pp. 17-19.

9 It shall be pointed out that there is an apparent lack of unanimity in defining smart contracts. Nonetheless, one can find the definition referring to a type of smart contracts executed on blockchain authoritative to some extent, as they prove to have the highest economic impact (cf. Szczerbowski, J.J. (2018a) Op. cit., pp. 15, 31-36; Szostek, D. (2018) Op. cit., pp. 120 et seq.; Durovic, M. and Janssen, A. (2018) Op. cit., pp. 754, 757 et seq.; Mik, E. (2017) Op. cit., p. 274; Caria, R. de. (2018) Op. cit., pp. 733 et seq.; Governatori, G. et al. (2018) On Legal Contracts, Imperative and Declarative Smart Contracts, and Blockchain System. Artificial Intelligence and Law, 26 (4), pp. 378, 385 et seq.; Giancaspro, M. (2017) Op. cit., pp. 826, 827; Levy, K.E.C. (2017) Book-Smart, Not Street-Smart: Blockchain-Based Smart Contracts and the Social Workings of Law. Engaging Science, Technology, and Society, 3, pp. 2-3). See also: Geiregat, S. (2018) Cryptocurrencies Are (Smart) Contracts. Computer Law $\mathcal{E}$ Security Review, 34 (5), p. 1148; Werbach, K. (2018) Op. cit., pp. 505, 523; Allen, J.G. (2018) Op. cit., p. 309. 
of imitation of conventional ones. ${ }^{16}$ Moreover, regardless of the quality of a specific neosemantism attributed to the examined concept, substantial controversies surround the intimation that allegedly the category of smart contracts demonstrates capability resembling human intelligence or exceptional operability and trustworthiness. ${ }^{17}$ This argument is reflected in an ongoing discussion associated with the search for an exact Polish language equivalent for the term in question. ${ }^{18}$

\section{CONCEPTUALISATION OF CONTRACT UNDER POLISH LAW: AN OUTLINE}

For the purpose of the analysis a synthetic insight into the concept of contract under Polish law is needed with the aim of providing a relevant point of reference. It should be indicated that there is no legal definition of contract in contemporary Polish private law system. ${ }^{19}$ According to the widely accepted doctrinal position, a contract shall be defined

10 Cf. Carron, B. and Botteron, V. (2019) How Smart Can a Contract Be?. In: D. Kraus, T. Obrist and O. Hari (eds.). Blockchains, Smart Contracts, Decentralised Autonomous Organisations and the Law. Cheltenham-Northampton: Edward Elgar Publishing, pp. 105 et seq.; Polański, P. (2019) Inwigilacja, dostępność, blockchain i sztuczna inteligencja: pytania o kierunki rozwoju prawa nowych technologii w erze rewolucji internetowej. Monitor Prawniczy, 2, p. 112; Woebbeking, M.K. (2019) The Impact of Smart Contracts on Traditional Concepts of Contract Law. Journal of Intellectual Property, Information Technology and E-Commerce Law, 10 (1), pp. 107-108; Szczerbowski, J.J. (2018a) Op. cit., pp. 14 et seq., 36 et seq.; Szczerbowski, J.J. (2018b) Transaction Costs of Blockchain Smart Contracts. Law and Forensic Science, 16 (2), pp. 1-2; Cannarsa, M. (2018) Op. cit., pp. 774-775, 776; Werbach, K. (2018) Op. cit., pp. 489 et seq., 504 et seq.; Druck, J.A. (2018) "Smart Contracts" Are Neither Smart Nor Contracts: Discuss. Banking \& Financial Services Policy Report, 37 (10), pp. 5 et seq.; Bacina, M. (2018) Op. cit., pp. 1, 16 et seq.; Giancaspro, M. (2017) Op. cit., p. 826; Kocot, W.J. (2017) Op. cit., pp. 950 et seq.; Hulicki, M. and Lustofin, P. (2017) Op. cit., pp. 38, 43 et seq.; Klinger, B. and Szczepański, J. (2017) Blockchain - historia, cechy i główne obszary zastosowań. Człowiek $w$ Cyberprzestrzeni, 1, pp. 14, 16-17; Scholz, L.H. (2017) Algorythmic Contracts. Stanford Technology Law Review, 20 (2), pp. 146 et seq.; Gambino, A. (2017) Dignità umana e mercato digitale. Diritto Mercato Tecnologia, pp. 12-13; Cieplak, J. and Leefatt, S. (2017) Smart Contracts: A Smart Way to Automate Performance. Georgetown Law Technology Review, 1 (2), pp. 417 et seq.

11 Cf. Scholz, L.H. (2017) Op. cit., pp. 146 et seq.; Szczerbowski, J.J. (2018a) Op. cit., pp. 36 et seq.; Mik, E. (2017) Op. cit., pp. 275 et seq. See also, including polemical remarks on blockchain as a "mechanism of trust": Werbach, K. (2018) Op. cit., pp. 490 et seq.

12 See Mik, E. (2017) Op. cit., pp. 271 et seq.; Mik, E. (2018) Op. cit., pp. 856 et seq. Cf. also Hulicki, M. and Lustofin, P. (2017) Op. cit., pp. 39-40; Szczerbowski, J.J. (2018a) Op. cit., pp. 15, 36; Werbach, K. (2018) Op. cit., pp. 489, 498-499. On distinct categories of smart contracts serving either as tools in contracting process or as "artificial agents", see: Durovic, M. and Janssen, A. (2018) Op. cit., pp. 759-761, 770.

13 Cf. Carron, B. and Botteron, V. (2019) Op. cit., p. 108 et seq.; Szczerbowski, J.J. (2018a) Op. cit., pp. 15-17, 35, 46 et seq., 121-122; Szostek, D. (2018) Op. cit., pp. 121 et seq.; Kasprzyk, K. (2018) The Concept of Smart Contracts from the Legal Perspective. Review of Comparative Law, 34 (3), pp. 115-116; Governatori, G. et al. (2018) Op. cit., pp. 2 et seq.; Allen, J.G. (2018) Op. cit., pp. 311 et seq.; Cannarsa, M. (2018) Op. cit., pp. 775 et seq.; Werbach, K. and Cornell, N. (2017) Contracts Ex Machina. Duke Law Journal, 67 (2), pp. 338 et seq., 368 et seq. 
as a juridical act $^{20}$ involving (at least) two parties and requiring unanimous declarations of intent. ${ }^{21}$ Worthy of note is that a definition of similar wording has been proposed within the framework of the recodification process in the previous draft of the book one of the new Polish civil code published in 2008 by the Civil Law Codification Commission at the Ministry of Justice, $^{22}$ eventually rejected upon its thorough revision in $2015 .^{23}$ Consistently, a historically conditioned approach based on consensus as a crucial element of contract remains of significant importance, along with the assumption according to which a contract shall be considered a socially relevant act. $^{24}$ As determined by current approach, a contract serves as an institution intended to enable autonomous private law entities to regulate legal relations by virtue of their own decisions, however, under

14 Cf. Durovic, M. and Janssen, A. (2018) Op. cit., pp. 761 et seq. On the category of contract and its functions in a comparative view, including references to historical determinants, cf. i.a.: Elizalde, F. de. (2018) The Sources and Effects of Contractual Terms: Towards Approximation of Common Law and Civil Law. In: F. de Elizalde (ed.). Uniform Rules for European Contract Law?: A Critical Assessment. Oxford: Hart Publishing, pp. 163-188; Zweigert, K. and Kötz, H. (2011) Introduction to Comparative Law. transl. T. Weir. Oxford: Clarendon Press, pp. 324 et seq.; Graziadei, M. (2007) Variations on the Concept of Contract in a European Perspective. In: R. Schulze (ed.). New Features in Contract Law. Munich: Sellier European Law Publishers, pp. 311 et seq. For more on the methodological demand to address comparative argument in examining private law institutions, alongside historical and dogmatic analyses thereof, see: Longchamps de Bérier, F. (2016) Z uwag do metodologii nauki prawa prywatnego: argumenty historyczny, dogmatyczny i prawnoporównawczy na przykładzie darowizny na wypadek śmierci oraz zapisu windykacyjnego. In: A. Wudarski (ed.). Polska komparatystyka prawa. Prawo obce w doktrynie prawa polskiego. Warszawa: Stowarzyszenie Notariuszy Rzeczypospolitej Polskiej, pp. 285-329.

15 On the criticism raised in this regard, cf.: Szczerbowski, J.J. (2018a) Op. cit., pp. 16-17; Durovic, M. and Janssen, A. (2018) Op. cit., pp. 755, 757 et seq. See also i.a.: Goldenfein, J. and Leiter, A. (2018) Op. Cit., pp. 141 et seq.; Cannarsa, M. (2018) Op. cit., pp. 775, 776 et seq.; Sklaroff, J.M. (2017) Op. cit., p. 276.

16 Cf. Szczerbowski, J.J. (2018a) Op. cit., p. 17. On smart contracts as "analogue" of legal agreements, see also: Cannarsa, M. (2018) Op. cit., p. 777.

17 Cf. Szczerbowski, J.J. (2018a) Op. cit., p. 16; Druck, J.A. (2018) Op. cit., pp. 5 et seq. See also: Durovic, M. and Janssen, A. (2018) Op. cit., p. 755; Levy, K.E.C. (2017) Op. cit., pp. 2 et seq. Mik, E. (2017) Op. cit., p. 287; Kolber, A.J. (2018) Not-So-Smart Blockchain Contracts and Artificial Responsibility. Stanford Technology Law Review, 21 (2), pp. 198-234; Werbach, K. (2018) Op. cit., pp. 515-516, 518, 527; Werbach, K. and Cornell, N. (2017) Op. cit., p. 369.

18 See: Szczerbowski, J.J. (2018a) Op. cit., pp. 14-17; Szostek, D. (2018) Op. cit., pp. 120 et seq.; Klinger, B. and Szczepański, J. (2017) Op. cit., p. 17; Kocot, W.J. (2017) Op. cit., pp. 950 et seq.

19 Cf. Brzozowski, A. (2013) Op. cit., pp. 420-421; Strugała, R. (2013b) Standardowe klauzule umowne: adaptacyjne, salwatoryjne, merger, interpretacyjne oraz pactum de forma. Warszawa: Wydawnictwo C.H. Beck, p. 15. By contrast, prerequisites required to be met for establishing the existence of a contract were provided for in art. 50 of the Code of Obligations which read that a contract is formed by a unanimous declaration of intent made by two parties one of which commits to render a performance and the other accepts this commitment $(\S 1)$ and that the subject matter of a contract may be also creation, modification or termination of a legal relation without commitment to render performance (§2). On this issue, see i.a.: Pecyna, M. (2013) Merger clause jako zastrzeżenie wyłaczności dokumentu, klauzula integralności umowy, reguła wykładni umowy. Warszawa: Lex a Wolters Kluwer Business, p. 179. 
authority and control of law. ${ }^{25}$ A key role is attributed to the freedom of contract principle, ${ }^{26}$ declaring that the parties entering into a contract may arrange the legal relation at their own discretion, on the condition that its content or purpose are not contrary to the nature of the relation, a normative act or principles of social coexistence. ${ }^{27}$ Within the above limits contracting parties are regarded competent ${ }^{28}$ to create specific rules binding between them (lex contractus), which influence the content of obligation. ${ }^{29}$ Theoretical construct of contractual freedom is based, to a material extent,

20 Juridical act is considered an essential instrument that serves to determine one's legal situation in the sphere of private law, within the framework of autonomy of will sensu largo. In the absence of legal definition, the concept of juridical act adopted in the doctrine refers to actions of entities in civil law, consisting at the very least in expressing a declaration of intent, aimed at producing legal effects which are recognised by material law as being intended by the parties. See: Radwański, Z. and Mularski, K. (2019b) Zagadnienia ogólne czynności prawnych. In: A. Olejniczak and Z. Radwański (eds.). System prawa prywatnego. 2: Prawo cywilne - część ogólna. Warszawa: Wydawnictwo C.H. Beck, pp. 13 et seq.; Grykiel, J. (2018). In: M. Gutowski (ed.). Kodeks cywilny. 1: Komentarz. Art. 1-352. Warszawa: Wydawnictwo C.H. Beck, pp. 507-509; Janas, A. (2018). In: M. Habdas and M. Fras (eds.). Kodeks cywilny. Komentarz. 1: Część ogólna (art. 1-125). Warszawa: Wolters Kluwer, pp. 461 et seq. It is argued that the research on juridical acts draws on the achievements of theory of law regarding so-called conventional acts, although respective precepts contained in the Civil Code have been determined by the legal tradition and deeply ingrained conceptual framework as well as objectives pursued by the codification (cf. Sobolewski, P. (2017). In: K. Osajda (ed.). Kodeks cywilny. Komentarz. 1: Część ogólna. Przepisy wprowadzajace kc. Prawo o notariacie (art. 78-95 i 96-99). Warszawa: Wydawnictwo C.H. Beck, pp. 488-490, 547; see also: Machnikowski, P. (2017a). In: E. Gniewek and P. Machnikowski (eds.). Kodeks cywilny. Komentarz. Warszawa: Wydawnictwo C.H. Beck, pp. 124, 139). On the characterisation of conventional acts, see i.a.: Radwański, Z. and Mularski, K. (2019b) Op. cit., pp. 11 et seq.; Czepita, S. (2017) On the Concept of a Conventional Act and Its Types. Ruch Prawniczy, Ekonomiczny i Socjologiczny, 79 (1), pp. 85-102. For more on the theory of juridical acts elaborated by the pandectists, see i.a.: Giaro, T. (2018) Kształtowanie i ochrona praw prywatnych. In.: W. Dajczak, T. Giaro, F. Longchamps de Bérier. Prawo rzymskie. U podstaw prawa prywatnego. Warszawa: Wydawnictwo Naukowe PWN, pp. 128 et seq.

21 Radwański, Z. and Olejniczak, A. (2018) Zobowiązania-część ogólna. Warszawa: Wydawnictwo C.H. Beck, pp. 122-124; Bierć, A. (2018) Zarys prawa prywatnego. Część ogólna. Warszawa: Wolters Kluwer, p. 710; Zagrobelny, K. (2018a) Umowy jako źródło zobowiązań. In: E. Gniewek and P. Machnikowski (eds.). Zarys prawa cywilnego. Warszawa: Wydawnictwo C.H. Beck, p. 247; Machnikowski, P., Balcarczyk, J. and Drela, M. (2017) Op. cit., pp. 29, 32, 68; Pecyna, M. (2013) Op. cit., p. 179. Under the Code of Obligations, the concept of contract denoted a unanimous expression of intent of two parties aimed at producing legal effects. For more on this issue, see: Longchamps de Bérier, R. (1938) Zobowiązania, Lwów: Księgarnia Wydaw. Gubrynowicz i Syn, p. 142; Samolewicz, S. (1937) Zarys polskiego prawa zobowiazań. Lwów: Skł. gł. Księgarnia T.S.L., p. 13.

22 See: Komisja Kodyfikacyjna Prawa Cywilnego działająca przy Ministrze Sprawiedliwości (2009) Księga pierwsza Kodeksu cywilnego. Projekt z uzasadnieniem. Warszawa: Wydawnictwo C.H. Beck, pp. 59 et seq. For more on the issue of Polish private law recodification, see also: Kaczorowska, M. (2009) Rekodyfikacja prawa cywilnego w Polsce wobec rozwoju europejskiego prawa prywatnego. Rozważania na tle projektu księgi pierwszej Kodeksu cywilnego. Ruch Prawniczy, Ekonomiczny i Socjologiczny, 3, pp. 19-29; Machnikowski, P. (2014) Poland. In: J. Hurdík, P. Lavický et al. (eds.). Private Law Reform. Brno: Masaryk University, pp. 197-212; Gnela, B. and Michałowska, K. (academic supervision) (2014) Directions of Private Law Development: Comments on the Draft of Book One of the Civil Code. Warszawa: Difin. 
upon regulatory (normative) character of a contract creating an obligation. ${ }^{30}$ In this regard, contract constitutes a norm-setting act, ${ }^{31}$ as reflected in the mechanism covering the effects it gives rise to. ${ }^{32}$ The underlying rule is declared to be of cardinal importance for the whole framework of the civil law system. ${ }^{33}$ Accordingly, a contract entails not only the effects expressed therein but also those that follow from a normative act, principles of social coexistence and established customs. ${ }^{34}$ Thus, in terms of determining the content of obligation, encompassing the rights and duties of the parties, the content of contract ascertained adequately within the process of its

23 See: Machnikowski, P. (2017b) In: P. Machnikowski (ed.). Kodeks cywilny. Księga pierwsza. Część ogólna. Projekt Komisji Kodyfikacyjnej Prawa Cywilnego przyjęty w 2015 r. z komentarzem członków Zespołu Problemowego KKPC. Warszawa: Wydawnictwo C.H. Beck, pp. XIII-XVI, 71 et seq.

24 Radwański, Z. and Olejniczak, A. (2018) Op. cit., p. 123. Cf. also: Bierć, A. (2018) Op. cit., p. 710; Machnikowski, P., Balcarczyk, J. and Drela, M. (2017) Op. cit., p. 68; Zagrobelny, K. (2018a) Op. cit., p. 247; Brzozowski, A. (2013) Op. cit., p. 421.

25 Cf. Radwański, Z. and Mularski, K. (2019b) Op. cit., pp. 9 et seq.; Radwański, Z. and Olejniczak, A. (2018) Op. cit., p. 123; Machnikowski, P. (2013b) Swoboda umów. In: System prawa prywatnego. 5, pp. 462-463; Machnikowski, P., Balcarczyk, J. and Drela, M. (2017) Op. cit., p. 87.

26 The normative expression of contractual freedom principle is art. $353^{1}$ of the Act of 23 April 1964 - Civil Code (ustawa - Kodeks cywilny, Journal of Laws of 2019 item 1145, as amended, hereinafter: the Civil Code).

27 Machnikowski, P., Balcarczyk, J. and Drela, M. (2017) Op. cit., pp. 34, 87; Machnikowski, P. (2013b) Op. cit., pp. 462 et seq.; Machnikowski, P. (2013c) Treść umowy. In: System prawa prywatnego. 5, pp. 510 et seq. For more on the principle of freedom of contracts and its limits resulting from public policy, normative act and good morals, under art. 55 of the Code of Obligations, see i.a.: Longchamps de Bérier, R. (1938) Op. cit., pp. 147-150.

28 For more on the category of competence considered adequate to define the freedom of contract, see: Radwański, Z. and Olejniczak, A. (2018) Op. cit., p. 132; Machnikowski, P. (2013b) Op. cit., pp. 463 et seq., 478 et seq.; Zagrobelny, K. (2018a) Op. cit., pp. 269-270; Strugała, R. (2013b) Op. cit., p. 66; Pecyna, M. (2013) Op. cit., p. 179.

29 Machnikowski, P. (2013b) Op. cit., pp. 478 et seq.; Machnikowski, P. (2013c) Op. cit., p. 504; Łolik, M. (2014) Op. cit., p. 29.

30 Machnikowski, P. (2013b) Op. cit., pp. 478 et seq.

31 Machnikowski, P. (2013b) Op. cit., pp. 478-481; Strugała, R. (2013b) Op. cit., pp. 21-22, 64.

32 For more on this issue, see: Machnikowski, P. (2013b) Op. cit., pp. 478 et seq.; Machnikowski, P., Balcarczyk, J. and Drela, M. (2017) Op. cit., p. 87.

33 Cf. Grykiel J. (2018) Op. cit., pp. 506 et seq.

34 See: art. 56 of the Civil Code. For more on this issue, cf.: Machnikowski, P. (2013b) Op. cit., pp. 478 et seq.; Machnikowski, P., Balcarczyk, J. and Drela, M. (2017) Op. cit., pp. 87-88. On the parallel mechanism adopted under art.60 of the Code of Obligations as to supplementing the content of contract in line with a normative act, usage and equity, see: Longchamps de Bérier, R. (1938) Op. cit., pp. 154-155. 
interpretation $^{35}$ constitutes but one among a number of factors to be considered. ${ }^{36}$

On account of a contract being perceived in essence as the parties' self-commitment, the pacta sunt servanda principle applies. It requires that the contract be performed in accordance with its content. ${ }^{37}$ Exemptions from this principle are allowed in certain cases on grounds of a statutory provision or the parties' common intent. ${ }^{38}$ Worthy of particular note is the attempt to harmonise the pacta sunt servanda principle with the rebus sic stantibus clause regarding the influence of a change of circumstances on obligations. ${ }^{39}$ One shall, however, draw attention to an argued need to reconsider the term pactum (agreement) represented in the above principle on account of currently identified symptoms of the so-called decodification process in the domain of private law. ${ }^{40}$ An important factor

35 Cf. Janas, A. (2018) Op. cit., p. 463; Machnikowski, P. (2017a) Op. cit., p. 152; Łolik, M. (2014) Op. cit., pp. 29, 47; Rott-Pietrzyk, E. (2013) Interpretacja umów w prawie modelowym i wspólnym europejskim prawie sprzedaży (CESL). Warszawa: Wydawnictwo C.H. Beck, pp.67-71. See also: Kaczorowska, B. (2018a) Wykładnia umów obligacyjnych w świetle wspótczesnych tendencji rozwoju prawa prywatnego. Wrocław: Wydawnictwo i Drukarnia Swiętego Krzyża, passim.

36 For more on this issue, see: Machnikowski, P. (2013b) Op. cit., pp. 478-481; Machnikowski, P. (2013c) Op. cit., pp. 504 et seq.; Grykiel, J. (2018) Op. cit., pp. 508, 514; Rott-Pietrzyk, E. (2013) Op. cit., p. 71.

37 Cf. Brzozowski, A. (2013) Op. cit., p. 421; Machnikowski, P. (2013a) Struktura zobowiązania. In: System prawa prywatnego. 5, p. 163; Zagrobelny, K. (2018b) Wykonanie zobowiązania. In: E. Gniewek and P. Machnikowski (eds.). Zarys prawa cywilnego..., p. 367. On the application of the pacta sunt servanda principle under the Code of Obligations, see: Longchamps de Bérier, R. (1938) Op. cit., p. 317.

38 Cf. Brzozowski, A. (2013) Op. cit., p. 421.

39 Cf. i.a.: Zagrobelny, K. (2018b) Op. cit., p. 367; Brzozowski, A. (2018) Wpływ zmiany okoliczności na zobowiązania. In: System prawa prywatnego. 6: A. Olejniczak (ed.). Prawo zobowiazań - część ogólna, Warszawa: Wydawnictwo C.H. Beck, pp. 1307 et seq.; Brzozowski, A. (2014) Wpływ zmiany okoliczności na zobowiazania. Klauzula rebus sic stantibus. Warszawa: Wydawnictwo C.H. Beck, pp. 3 et seq.; Machnikowski, P., Balcarczyk, J. and Drela, M. (2017) Op. cit., pp. 126, 127; Gorczyński, G. (2015) Klauzula rebus sic stantibus w XXI wieku. In: A. Olejniczak et al. (eds.). Wspótczesne problemy prawa zobowiąań..., pp. 186 et seq. See also, in the context of commercial contracts: Włodyka, S. and Spyra, M. (2017) Ogólna charakterystyka umów handlowych. In: M. Stec (ed.). System prawa handlowego. 5: Prawo umów handlowych, Warszawa: Wydawnictwo C.H. Beck, pp. 22, 23. On recognition of the rebus sic stantibus clause under art. 269 of the Code of Obligations, see also: Longchamps de Bérier, R. (1938) Op. cit., pp. 404 et seq.; Giaro, T. (2013) Op. cit., pp. 43-44. For more on the issue regarding promise-keeping juxtaposed with the consequences of a significant change of circumstances in historical perspective and in contemporary private law systems, cf.: Dajczak, W. (2018) Zobowiązania. In: W. Dajczak, T. Giaro, F. Longchamps de Bérier. Prawo rzymskie..., pp. 523-524.

40 Dajczak, W. (2017) Amerykańska zapowiedź "śmierci umowy” na tle tradycji romanistycznej. In: F. Longchamps de Bérier (ed.). Dekodyfikacja prawa prywatnego. Szkice do portretu. Warszawa: Wydawnictwo Sejmowe, pp. 89 et seq., 100-101. Cf. Longchamps de Bérier, F. (2019) Decodification of Contract Law. In: C. Su, F. Longchamps de Bérier and P. Grzebyk (eds.). Theory and Practice of Codification: The Chinese and Polish Perspectives. Beijing: Social Sciences Academic Press, pp.137-149. For more on the phenomenon of private law decodification, see also i.a.: Rudnicki, J. (2018) Dekodyfikacja prawa cywilnego $w$ Polsce. Bielsko-Biała: Wydawnictwo Od.Nowa. 
to be reckoned with under this approach shall be the crisis of the liberal theory of contract as an expression of the parties' autonomy of will, as well as the 19th century paradigm of civil law codification designed as a comprehensive system with a view to ensuring the certainty of law. ${ }^{41}$ Consequently, mainly in case of a considerable asymmetry between the contracting parties' positions, particular significance is attached to legitimate, justifiable expectations of the creditor. Therefore, in the light of the assumed redefinition of the concept of pactum in the foregoing context, when determining the due performance the priority is envisaged to be given to "what could have been justifiably expected by the creditor at the contracting stage" instead of "what has been planned substantively". ${ }^{42}$ Pursuant to this view, what shall be anticipated is a systemic change to law of contractual obligations expressed by surpassing in a far-reaching manner the content of the parties' declarations of intent as well as statutory provisions in order to retrieve the social and economic sense of contract. ${ }^{43}$

Against this particular background delineated above, taking into account the multidimensional ambience in which, essentially, any research devoted to the very nature of contract and contractual obligation shall be placed, a critical analysis outlining some aspects of the smart contracts' juridical import will be undertaken.

\section{CRITICAL ANALYSIS OF SMART CONTRACTS' JURIDICAL RELEVANCE: AN OUTLINE}

As argued in doctrine, the principal classification of blockchain-based smart contracts encompasses the following categories: cryptocurrencies which constitute chronologically the first implementation of blockchain technology aimed at creating an uncomplicated system of cryptographic units transfer, on the one hand, and so-called complete smart contracts

41 Dajczak, W. (2017) Op. cit., pp. 90, 101.

${ }^{42}$ Dajczak, W. (2017) Op. cit., pp. 100-101. Cf. also: Longchamps de Bérier, F. (2019) Op. cit., p. 147.

43 Dajczak, W. (2017) Op. cit., p. 101. Cf. also: Dajczak, W. (2012) The Nature of the Contract in Reasoning of Civilian Jurists. Poznań: Wydawnictwo Naukowe UAM, pp. 175-176. What constitutes a relevant research issue in this respect is the comparison between civil law system and common law framework on the basis of the criterion of adaptability to the aforementioned decodification consequences (Dajczak, W. (2017) Op. cit., pp. 101-102). Correspondingly, a theoretical approach and contract drafting techniques characteristic respectively for civil law and common law are subject to a comparative analysis in the light of the phenomenon of automation of legal relations, with the emphasis on coding contracts (see: Cannarsa, M. (2018) Op. cit., pp. 776, 781-782). 
utilising multifunctional programming languages, on the other hand. ${ }^{44}$ Due to the properties of programming languages complete smart contracts are deemed capable of expressing content of any relation and therefore necessitate being explored in more detail from the viewpoint of contract law. ${ }^{45}$ In this regard the scrutiny of smart contracts' juridical relevance shall be preceded by drawing a distinction between dissimilar types of them. It is emphasised that one shall differentiate a smart contract itself embodying the binding expression of an agreement - as the only form of record (smart contract entirely written in code), from a smart contract implementing automatically a separate agreement expressed in natural language, and thus serving as evidence for the existence and the content of a conventional agreement (as a tool or carrier of a record reflecting a prior traditional contract frequently being a framework agreement or a conditional contract in nature $)^{46}$. The former category, referred to as pure complete smart contracts, $^{47}$ both instantiated and executed in a direct manner on the blockchain, warrants in particular closer attention. However, mainly due to complications connected substantially with translation of natural language contract into smart contract code, material legal problems have to be addressed also in regard to the latter category.

In formal terms, there is no impediment to express a legally relevant arrangement in a computer code by means of blockchain technology. As a general rule, freedom of declaration of intent form is enshrined under the Civil Code. ${ }^{48}$ Accordingly, subject to statutory exceptions the intention

${ }^{44}$ Cf. Szczerbowski, J.J. (2018a) Op. cit., pp. 13-14, 46 et seq., 60 et seq. See also: Geiregat, S. (2018) Op. cit., pp. 1144-1149; Szostek, D. (2018) Op. cit., pp. 51 et seq., 113 et seq.

45 Cf. Szczerbowski, J.J. (2018a) Op. cit., pp. 49 et seq.

${ }^{46}$ Carron, B. and Botteron, V. (2019) Op. cit., pp. 111 et seq.; Governatori, G. et al. (2018) Op. cit., p. 378; Szostek, D. (2018) Op. cit., pp. 121-122, 123-124; Cannarsa, M. (2018) Op. cit., pp. 776-777; Durovic, M. and Janssen, A. (2018) Op. cit., pp. 756, 759 et seq. Another, threefold distinction embraces respectively: so-called pure complete smart contracts, both formed and executed directly on a blockchain; hybrid complete smart contracts, formed on the blockchain but executed outside it, including those requiring an external input managed by a third system; smart contracts constituting components of traditional contracts, including smart contracts templates intended to associate natural language pertaining to contractual transactions with smart contract code (for more, see: Szczerbowski, J.J. (2018a) Op. cit., pp. 50-53, 121-122). On smart contract templates cf.: Hulicki, M. and Lustofin, P. (2017) Op. cit., pp. 44. 46; Werbach, K. (2018) Op. cit., pp. 542-543. On the interrelation between programming code and natural language in the sphere of smart contracts, including direct coding and contract translation, cf.: Mik, E. (2017) Op. cit., pp. 287 et seq.; DiMatteo, L.A. and Poncibò, C. (2018) Op. cit., pp. 807 et seq. See also i.a.: Allen, J.G. (2018) Op. cit., pp. 312 et seq., 319; Scholz, L.H. (2017) Op. cit., pp. 146-147; Cieplak, J. and Leefatt, S. (2017) Op. cit., pp. 417-418.

47 Szczerbowski, J.J. (2018a) Op. cit., pp. 50-51, 121, 132.

48 See: art. 60 of the Civil Code. 
of a person performing a juridical act may be expressed by any behaviour which manifests that person's intention sufficiently, including the intention being manifested in electronic format, it is hence possible to select any form of sign or means of communication as well as configuration thereof. ${ }^{49}$ In this regard, principally, smart contracts shall be granted legal relevance, as a specific expression of the parties' intent to cause legal effect consisting in creation, modification or termination of a civil law relation. ${ }^{50}$ However, dual requirement must be taken into account when determining the completion of a declaration of intent as defined by Polish law. Any declaration of intent needs to be externalised so that it proves to be discernible, and manifested in a sufficient manner, that is in such a mode as to render it intelligible for the addressee. The latter refers not only to the type of signs used by the party performing a juridical act but also to the language, required to be at least decodable by the addressee, as well as to the way in which the respective wording is phrased. ${ }^{51}$ What constitutes an essential condition on this point is that the content of a declaration be unambiguously identifiable by use of interpretation methods, otherwise, in failure to establish any reasonable meaning of a given conduct, there are no grounds to recognise it as the completion of a declaration of intent. ${ }^{52}$

In the above context, a particular question arises over the specificity of machine-readable format of the arrangement encoded in a smart contract. It is argued that the apprehension of the smart contract's content poses considerable difficulties, mainly due to the artificial programming languages intricacies, ${ }^{53}$ with a risk of abuse by one party of the incomplete understanding by the other. ${ }^{54}$ Conceivably, it concerns both pure complete smart contracts formed and enforced entirely in the code and those originated as contractual documents drafted in natural language to be

49 For more on this issue, see: Grykiel, J. (2018) Op. cit., p. 593; Górska, K. (2018) Czynności prawne na tle innych zdarzeń cywilnoprawnych. In: E. Gniewek and P. Machnikowski (eds.). Zarys prawa cywilnego..., pp. 169 et seq.; Zagrobelny, K. (2018) Op. cit.., p. 277; Machnikowski, P., Balcarczyk, J. and Drela, M. (2017) Op. cit., pp. 29, 57; Machnikowski, P. (2017a) Op. cit., p.140. Cf. The Civil Code. Kodeks cywilny (2019). E. Kucharska (transl.). Warszawa: Wydawnictwo C.H. Beck, pp. 38-39.

50 Cf. Szczerbowski, J.J. (2018a) Op. cit., pp. 35, 98-90, 101, 183.

51 Cf. Grykiel, J. (2018) Op. cit., pp. 593-594; Janas, A. (2018) Op. cit., p. 531.

52 Cf. Janas, A. (2018) Op. cit., p. 531; Sobolewski, P. (2018) Op. cit., pp. 547-548.

53 It should be noted that in legal analyses of smart contracts attention is drawn to declarative programming languages as a possible alternative to imperative programming languages, currently dominant as far as smart contract coding is concerned. Declarative languages are expected to prove more readily understandable and facilitate drafting smart contract content. For more on this issue, see: Governatori, G. et al. (2018) Op. cit., pp. 378, 387 et seq.; Szostek, D. (2018) Op. cit., pp. 125-126. 
translated consecutively into code.$^{55}$ Additional determinant affecting smart contracts comprehensibility is the sequence of code conversions required in order to render the programme executable. The initial source codewhile to some extent retaining intelligibility owing to its resemblance to natural language - is then subject to conversion into assembler code which, in turn, necessitates to be compiled into machine-executable bytecode. $^{56}$ Consequently, there is a growing possibility of divergence between the parties' common intent and the smart contract programme executed automatically. ${ }^{57}$

What shall be viewed as a highly problematic issue in that regard is the interpretation of smart contracts' content. This is mostly due to the particularity of interpretation based on the operation of source code compiler. $^{58}$ In the light of the above considerations, the question as to possible replacement of contractual interpretation in the juridical sense by machine-driven interpretation pertaining to smart contracts as well as the very legal relevance of the latter, requires critical assessment. ${ }^{59}$ Whilst, on the one hand, it is argued that the existing contract law interpretative rules do not apply to machine-based interpretation of smart contracts, ${ }^{60}$ on the other there are calls for judicial activity supporting rational implementation of the Civil Code provisions regarding contractual interpretation in the domain of smart contracts. ${ }^{61}$ In line with a widely accepted approach, interpretation process encompasses a set of operations

54 An additional factor emphasised in this regard is that programming languages used to create smart contracts, as well as their compilers, continue to evolve rapidly which renders them prone to errors (see: Szczerbowski, J.J. (2018a) Op. cit., pp. 122, 133-134, 184). For more on the consequences of the unintelligibility of programming languages used to code smart contracts, cf. also: Carron, B. and Botteron, V. (2019) Op. cit., p. 129; Cannarsa, M. (2018) Op. cit., p. 784; Giancaspro, M. (2017) Op. cit., pp. 831 et seq.

55 For more on this issue, see: Cannarsa, M. (2018) Op. cit., pp. 777 et seq.; Giancaspro, M. (2017) Op. cit., pp. 831 et seq.; Mik, E. (2017) Op. cit., pp. 287 et seq.

56 Cf. Szczerbowski, J.J. (2018a) Op. cit., pp. 133-135, 184. See also: Allen, J.G. (2018) Op. cit., pp. 331, 336; Governatori, G. et al. (2018) Op. cit., pp. 387, 395, 405-406.

57 Szczerbowski, J.J. (2018a) Op. cit., p. 135. Cf. also: Cannarsa, M. (2018) Op. cit., pp. 781, 784.

58 For more on this issue, see: Governatori, G. et al. (2018) Op. cit., pp. 393 et seq.; Szczerbowski, J.J. (2018a) Op. cit., pp. 13-14, 133 et seq. Cf. also: Giancaspro, M. (2017) Op. cit., pp. 831, 832-833.

59 For more on the comparative study of the issue of contractual interpretation in the light of deterministic nature of computer languages, including mainly differences between common law and civil law approaches to contract drafting techniques and interpretation of contracts, see: Cannarsa, M. (2018) Op. cit., pp. 779-780, 782, 883.

${ }^{60}$ Savelyev, A. (2017) Op. cit., p. 125.

${ }^{61}$ Cf. Szczerbowski, J.J. (2018a) Op. cit., p. 133. On the need for ascertaining a way for courts to interpret automated contracts, see: Cannarsa, M. (2018) Op. cit., p. 785. Cf. also: DiMatteo, L.A. and Poncibò, C. (2018) Op. cit., pp. 808, 809. 
leading subsequently towards establishing whether a given expression (arrangement of signs) manifested by the party performs the regulatory function and therefore constitutes a declaration of intent, and afterwards identifying its legally relevant meaning. ${ }^{62}$ The general interpretative rules applicable to contracts in Polish private law are structured according to so-called combined (subjective-objective) method which is axiologically conditioned. ${ }^{63}$ The methodology of interpretation process aims at considering respectively, to the extent appropriate, the real intention of the subject performing the declaration of intent (which refers also to the common intent of the contracting parties) and the reliance of third parties as well as the certainty of legal transactions. ${ }^{64}$ Thus, a declaration of intent shall be interpreted so as is required, in view of the circumstances in which it was made, by principles of social coexistence and established customs, whereas in contracts, one should examine the common intention of the parties and the aim of the contract rather than rely on its literal wording. ${ }^{65}$ Several characteristics of the process of smart contracts coding need to be analysed on this point. Essentially, the necessity to predetermine in advance, in a precise and comprehensive manner every condition to be met in order to automatically perform a predefined action, raises doubts as to consistency with the contract law framework, including the contractual interpretation model. The use of programming languages which serve to code smart contract terms results in considerable inflexibility that is found incompatible with both the inherent peculiarities and axiology of contract law and contract drafting practice. ${ }^{66}$ Yet, private law general clause $^{67}$ and open-textured standards (such as good faith, reasonableness or due diligence) are of vital importance for contractual interactions. ${ }^{68}$ The reference to the general clause of "principles of social coexistence" ${ }^{69}$ in the interpretative regime serves as a criterion according to which among a number of possible interpretation results one shall prefer the meaning of the contractual clause that proves to the highest degree in conformity

62 Cf. i.a.: Grykiel, J. (2018) Op. cit., pp. 641-642; Machnikowski, P. (2017a) Op. cit., p. 151.

63 See i.a.: Radwański, Z. and Mularski, K. (2019a) Wykładnia oświadczeń woli. In: A. Olejniczak and Z. Radwański (eds.). System prawa prywatnego. 2, pp. 85 et seq.; Grykiel, J. (2018) Op. cit., p. 647; Machnikowski, P. (2017a) Op. cit., pp. 152-153; Machnikowski, P., Balcarczyk, J. and Drela, M. (2017) Op. cit., pp. 101-102; Rott-Pietrzyk, E. (2013) Op. cit., pp. 23 et seq., 67 et seq. Cf. also: Kaczorowska, B. (2018a) Op. cit., pp. 289 et seq.

64 Cf. Radwański, Z. and Mularski, K. (2019a) Op. cit., pp. 85-86; Machnikowski, P. (2017a) Op. cit., p. 152; Grykiel, J. (2018) Op. cit., pp. 647-648; Bierć, A. (2018) Op. cit., pp. 763-766.

65 See: art. 65 of the Civil Code. For more on this issue, cf. i.a.: Machnikowski, P., Balcarczyk, J. and Drela, M. (2017) Op. cit., pp. 98 et seq.; Rott-Pietrzyk, E. (2013) Op. cit., pp. 67 et seq. 
with binding moral norms. ${ }^{70}$ Such objectivised interpretation involving the standard of accordance with moral norms is viewed in relation to the requirement of due diligence and so-called reasonableness test, assuming not only rationality of judgements but also a demand for honest and fair conduct. ${ }^{71}$ By contrast, it results exceedingly difficult to give effect to the above interpretative criteria within the operation of the smart contract source code compiler as the abstract concepts referred to in the aforementioned general clauses prove ineligible to be represented as an algorithm, and therefore untranslatable into a computer processable

${ }^{66}$ Cf. i.a.: Sklaroff, J.M. (2017) Op. cit., pp. 267, 277 et seq., 291 et seq.; DiMatteo, L.A. and Poncibò, C. (2018) Op. cit., pp. 813-814; Druck, J.A. (2018) Op. cit., pp. 7-9; Levy, K.E.C. (2017) Op. cit., p. 10; Mik, E. (2017) Op. cit., pp. 292 et seq.; Hsiao, J.I.-H. (2017) Op. cit., pp. 690-691. See also: Szczerbowski, J.J. (2018a) Op. cit., p. 18; Werbach, K. and Cornell, N. (2017) Op. cit., p. 367. It should be noted that attention is drawn to resemblance between the mechanism pertaining to smart contract coding and the practice of inserting entire agreement clauses (merger clauses) in contracts in writing (on this issue cf.: Cannarsa, M. (2018) Op. cit., pp. 782-783). For more on the effectiveness of merger clauses from Polish contract law perspective, see i.a.: Machnikowski, P. (2015a) Merger Clause in Contracts under Polish Law. In: B. Gessel-Kalinowska vel Kalisz (ed.). The Challenges and the Future of Commercial and Investment Arbitration: Liber Amicorum Professor Jerzy Rajski. Warsaw: Lewiatan Court of Arbitration, pp. 182-190; Strugała, R. (2013a) Merger Clauses in Contracts Governed by Polish Law. Wroclaw Review of Law, Administration and Economics, 3 (1), pp. 14-27; Pecyna, M. (2013) Op. cit., passim. For more on arguments provided to demonstrate compatibility of "smart contracting" with English law rules regarding contract formation, see: Durovic, M. and Janssen, A. (2018) Op. cit., pp. 761 et seq.

${ }_{67}$ General clauses perform multiple functions in the field of contract law, one of which is the interpretative function. For more on this issue, cf. i.a.: Rott-Pietrzyk, E. (2010) Klauzule generalne a wykonanie zobowiązania (z uwzględnieniem koncepcji systemu klauzul generalnych w projekcie kc). In: E. Gniewek, K. Górska and P. Machnikowski (eds.). Zaciaganie i wykonywanie zobowiązań. Materiaty III Ogólnopolskiego Zjazdu Cywilistów (Wrocław, 25-27.9.2008 r.). Warszawa: Wydawnictwo C.H. Beck, pp. 327-342; Machnikowski, P., Balcarczyk, J. and Drela, M. (2017) Op. cit., p. 100; Wilejczyk, M. (2014) Zagadnienia etyczne części ogólnej prawa prywatnego. Warszawa: Wydawnictwo C.H. Beck, pp. 65 et seq.; Piaskowy, A. (2012) Klauzule generalne w projekcie nowego kodeksu cywilnego. Transformacje Prawa Prywatnego, 3, pp. 49-67.

${ }_{68}$ Cf. i.a.: Carron, B. and Botteron, V. (2019) Op. cit., p. 115; Woebbeking, M.K. (2019) Op. cit., p. 109; DiMatteo, L.A. and Poncibò, C. (2018) Op. cit., pp. 809-810, 813; Giancaspro, M. (2017) Op. cit., pp. 831, 833; Mik, E. (2017) Op. cit., p. 294. See also: Machnikowski, P., Balcarczyk, J. and Drela, M. (2017) Op. cit., pp. 25-26.

${ }^{69}$ Formerly, under art. 107 of the Code of Obligations the major interpretative criterion was the concept of good faith in an objective sense. Along with the rule of interpretation in conformity with usages of fair dealing it was perceived as an instrument to ensure a higher ethical standard of contractual transactions (cf. Longchamps de Bérier, R. (1938) Op. cit., pp. 138 et seq.). On the relevance of the categories of good faith and usages of fair dealing in key conceptual framework pertaining to the Code of Obligations, see: Mańko, R. (2016) Towards a Typology of Dimensions of the Continuity and Discontinuity of Law: The Perspective of Polish Private Law after the 1989 Transformation. Wroclaw Review of Law, Administration and Economics, 6 (2), p. 114.

70 Radwański, Z. and Mularski, K. (2019a) Op. cit., pp. 98-100; Machnikowski, P. (2017a) Op. cit., p. 153; Machnikowski, P. (2010) Op. cit., p. 124. See also: Machnikowski, P., Balcarczyk, J. and Drela, M. (2017) Op. cit.., p. 100; Bierć, A. (2018) Op. cit., pp. 770, 771, 774; Wilejczyk, M. (2014) Op. cit., pp. 226-227. For more on criticism towards adoption of a general clause based on moral judgements as an interpretative criterion in the recodification process, cf.: Machnikowski, P. (2017b) Op. cit., p. 85. 
code. $^{72}$ Furthermore, the criterion of contextual interpretation is of substantial importance. ${ }^{73}$ So-called situational context required to be taken into account by the interpreter encompasses external recognisable circumstances accompanying the performance of a declaration of intent. ${ }^{74}$ The aforementioned elements become increasingly relevant in consideration of the foregoing tendency towards adopting more flexible approach to perception of the pacta sunt servanda principle, under which the judge shall be expected to give wider attention to extra-contract elements when reconstructing the relevant sense of the agreement. ${ }^{75}$ In this regard, what shall be emphasised is the weightiness of context-dependent open-textured terms guaranteeing semantic flexibility characteristic of conventional contracts drafted in natural language. ${ }^{76}$ On the contrary, the possibility to reach compliance with open-textured standards in the sphere of smart contracts is generally eliminated as far as any contractual term ambiguity or purposeful vagueness are viewed as inefficiencies smart contract mechanism is called to remove. ${ }^{77}$ As another point of view, however, the line of reasoning aimed at demonstrating purported unambiguous

${ }^{71}$ Cf. i.a.: Radwański, Z. and Mularski, K. (2019a) Op. cit., pp. 96 et seq.; Bierć, A. (2018) Op. cit., pp. 770-771; Wilejczyk, M. (2014) Op. cit., pp. 223-226; Rott-Pietrzyk, E. (2013) Op. cit., pp. 68-69. For more on the interpretative criterion of reasonable understanding of a party's declaration proposed in the revised draft of the book one of the new Polish civil code of 2015, see: Machnikowski, P. (2017b) Op. cit., pp. 83-85.

72 Cf. Mik, E. (2017) Op. cit., p. 294. See also: Carron, B. and Botteron, V. (2019) Op. cit., pp. 115 et seq.; Parola, L., Merati, P. and Gavotti, G. (2018) Blockchain e smart contract: questioni giuridiche aperte. I Contratti, 6, p. 686; Cannarsa, M. (2018) Op. cit., p. 785; Allen, J.G. (2018) Op. cit., pp. 336-338; Werbach, K. (2018) Op. cit., p. 527; Szczerbowski, J.J. (2018) Op. cit., p. 102; Bacina, M. (2018) Op. cit., p. 19; Giancaspro, M. (2017) Op. cit., p. 833; Sklaroff, J.M. (2017) Op. cit., p. 294. A separate issue to be considered is the means to interface the operation of smart contracts with the occurrences taking place outside the blockchain (for more on this aspect, see i.a.: Mik, E. (2017) Op. cit., pp. 278, 294-298; Durovic, M. and Janssen, A. (2018) Op. cit., p. 760; Szczerbowski, J.J. (2018a) Op. cit., pp. 130-132; 183-184; Werbach, K. (2018) Op. cit., pp. 545-548; Allen, J.G. (2018) Op. cit., pp. 337-338).

${ }^{73}$ It is argued that acontextual interpretation of contracts shall be excluded (cf. Rott-Pietrzyk, E. (2013) Op. cit., pp. 49, 71).

74 For more on this issue, see i.a.: Machnikowski, P. (2017a) Op. cit., p. 155; Machnikowski, P., Balcarczyk, J. and Drela, M. (2017) Op. cit., pp. 99-100; Grykiel, J. (2018) Op. cit., pp. 655-656.

75 Dajczak, W. (2017) Op. cit., p. 101.

76 Cf. Governatori, G. et al. (2018) Op. cit., pp. 381, 396; Sklaroff, J.M. (2017) Op. cit., pp. 281 et seq.; Werbach, K. (2018) Op. cit., p. 527; Mik, E. (2017) Op. cit., p. 292. On this issue, with particular consideration of the relevance of inferences drawn from the context that shall affect the interpretation of smart contract code, see also: Allen, J.G. (2018) Op. cit., pp. 339-340. For more on the role of contract law intervention in the sphere of contracts which prove by their very nature incomplete, as the parties are unable to anticipate every future contingency when drafting a contract, cf.: Rodrigues, U.R. (2019) Law and the Blockchain. Iowa Law Review, 104 (2), pp. 681 et seq.

77 See i.a.: Woebbeking, M.K. (2019) Op. cit., p. 109; Allen, J.G. (2018) Op. cit., pp. 336-338; DiMatteo, L.A. and Poncibò, C. (2018) Op. cit., pp. 812, 818; Sklaroff, J.M. (2017) Op. cit., pp. 263 et seq.; Mik, E. (2017) Op. cit., pp. 292-293. Cf. also: Savelyev, A. (2017) Op. cit., p. 125. 
nature of a smart contract coded in programming languages is contested since it is persuaded that instead of eliminating ambiguity smart contracts only disguise it, as the technical process of determining the semantics of any computer programme actually proves to be socially contingent. ${ }^{78}$ Moreover, the anonymity constituting a key feature of the mechanism underpinning smart contracts excludes the recourse to the interpretative criterion of commercial context when establishing the meaning of particular terms, hence substantially preventing their adequate implementation. ${ }^{79}$ Accordingly, automated (machine-driven) interpretation of algorithmised smart contract terms does not permit to achieve an appropriate objective contract law pursues to reach in order to establish the content of the contracting parties' rights and obligations. What is more, as argued in critical research, in contrast to alleged smart contracts' self-sufficiency in the sphere of interpretation, the prospect for surmounting the interpretative difficulties intrinsic to conventional contracts shall be denied. $^{80}$ It seems therefore reasonable to exclude the eventuality of contractual interpretation being reduced to automated smart contract mechanism. $^{81}$

Given the above properties of smart contracts "self-interpretation" and the constraints ensuing from the use of programming languages, arguably in like manner the operation designed to establish the content of obligation stemming from the arrangement instantiated in smart contract results discomposed. Yet, as reported previously, the juridical scheme of determining the legal effects a contract is supposed to produce requires its content to be properly established in the interpretation process but also involves regard to general clauses, in this case performing the normative function. $^{82}$ Consequently, the application of normatively required determinants regarding the due manner of the performance of contractual

78 Grimmelmann, J. (2019) All Smart Contracts Are Ambiguous. University of Pennsylvania Journal of Law and Innovation (forthcoming). [online] Available from: https://ssrn.com/ abstract=3315703 [Accessed 28 January 2019], pp. 2, 9 et seq. Cf. also: DiMatteo, L.A. and Poncibò, C. (2018) Op. cit., p. 811.

79 Sklaroff, J.M. (2017) Op. cit., pp. 262, 291, 295 et seq. Cf. Szostek, D. (2018) Op. cit., p. 122. On the negative consequences of the parties' anonymity, see also: Werbach, K. (2018) Op. cit., p. 528; Bacina, M. (2018) Op. cit., p. 21.

80 See: DiMatteo, L.A. and Poncibò, C. (2018) Op. cit., p. 811.

81 Cf. also: Bobrowicz, P. (2017) Psychologiczny kontekst oraz domniemania interpretacyjne i normy prawne w wykładni oświadczeń woli. Prawo $i$ Więź, 3, pp. 59-60.

82 Cf. Radwański, Z. and Olejniczak, A. (2017) Prawo cywilne- część ogólna. Warszawa: Wydawnictwo C.H. Beck, p. 293; Wilejczyk, M. (2014) Op. cit., pp. 231 et seq.; Rott-Pietrzyk, E. (2010) Op. cit., pp. 327 et seq., 333-334, 337-338. 
obligation is to be excluded in the field of smart contracts. Thus, the obligation shall be performed in accordance with its content and in a manner consistent with its socio-economic purpose as well as with principles of social coexistence and if established customs exist in this respect, also consistent with these customs. ${ }^{83}$ It is argued that "auto-executability" perceived as a smart contracts' distinctive feature corresponds to performance in a technological sense, and not in a contract law sense. ${ }^{84}$ Another issue necessitating further critical appraisal is the consequence of smart contract automated enforcement resulting virtually in - apparently misconceived - "absolutisation" of the pacta sunt servanda principle and, hence, purported elimination of the contract law remedies aimed at protecting the creditor. ${ }^{85}$ In substance, because of ineluctability of autonomous, algorithm-based implementation of the antecedently programmed action, the possibility that a smart contract be breached is supposed to be entirely excluded ${ }^{86}$ It is thus maintained that the mechanism of smart contracts itself ensures unquestionable performance, rendering the variety of institutionalised remedies and securities unnecessary and pointless. ${ }^{87}$ Moreover, immutability of code claimed as an essential quality of blockchain-based smart contracts precludes - in principle - their adaptation in case of change of circumstances. ${ }^{88}$ The aforesaid characteristics attributed to smart contracts stand in contrast to the juridical output developed in the sphere of contractual obligations. Indeed, it is argued that contract law is defined

83 See: art. 354 of the Civil Code. For more on this issue, cf.: Machnikowski, P., Balcarczyk, J. and Drela, M. (2017) Op. cit., p. 88. It shall be noted that formerly art. 189 of the Code of Obligations adopted a general principle that the obligation be performed in accordance with its content, in a manner consistent with the requirements of good faith and with usages of fair dealing (cf. Longchamps de Bérier, R. (1938) Op. cit., pp. 317-319).

84 See: Polański, P. (2019) Op. cit., p. 112.

85 Savelyev, A. (2017) Op. cit., p. 130. For more on this issue, including polemical remarks, see i.a.: Cannarsa, M. (2018) Op. cit., p. 781; DiMatteo, L.A. and Poncibò, C. (2018) Op. cit., pp. 805-824; Werbach, K. and Cornell, N. (2017) Op. cit., pp. 318 et seq.; Raskin, M. (2017) Op. cit., pp. 310-311. Cf. also: Kaczorowska, B. (2018b) Zarys problematyki „prawa umów in statu renascendi". In: A. Dańko-Roesler et al. (eds.). Ius est ars boni et aequi. Księga pamiatkowa dedykowana Profesorowi Józefowi Frąckowiakowi. Wrocław: Stowarzyszenie Notariuszy Rzeczypospolitej Polskiej, p. 404.

86 Savelyev, A. (2017) Op. cit., pp. 127, 130. On this issue see also: Caria, R. de. (2018) Op. cit., p. 740; DiMatteo, L.A. and Poncibò, C. (2018) Op. cit., p. 818; Werbach, K. and Cornell, N. (2017) Op. cit., p. 318.

87 Savelyev, A. (2017) Op. cit., p. 130.

88 Savelyev, A. (2017) Op. cit., pp. 127-130. On this issue, cf. also: Carron, B. and Botteron, V. (2019) Op. cit., pp. 120-121; Woebbeking, M.K. (2019) Op. cit., p. 110. 
first and foremost by its remedial function and ex post intervention. ${ }^{89}$ What deserves particular emphasis in this respect is the universality of Roman law experience with regard to creditor's remedies in the event of nonperformance of obligation..$^{90}$ On the contrary, the algorithm-driven operation of code involves ex ante determination of the whole course of transaction, which is expected to lead towards smart contracts' selfsufficiency, calling into question the ex post adjudication model. ${ }^{91}$ This tends to imply a reversal of elementary functions ascribed to the law of contractual obligations. ${ }^{92}$ Further, it should be underlined that the requirement to honour contractual promises reflected in the pacta sunt servanda principle never operated as a principle being absolute in character. ${ }^{93}$ As mentioned previously, one of the vital exceptions to the pacta sunt servanda rule is the rebus sic stantibus clause recognised under Polish law. In these terms, the pursuit of efficiency and certainty of transactions to be achieved through unarguable execution of pre-defined terms encoded into a smart contract contradicts the need for flexibility which is met by the law of contractual obligations.

\section{CONCLUSION}

In the light of the above remarks, it shall be assumed that there are grounds to consider some aspects of so-called smart contracts in terms of private law constructs, however, with a number of reservations. Most of these follow from the incompatibility between the properties of the mechanism underlying smart contracts and the intrinsic value system pertaining to contract law. The main smart contracts' inadequacy appears to amount to substantial dehumanisation of transactional process. ${ }^{94}$

89 See: Werbach, K. (2018) Op. cit., p. 544; Werbach, K. and Cornell, N. (2017) Op. cit., pp. 318 et seq. Cf. DiMatteo, L.A. and Poncibò, C. (2018) Op. cit., pp. 813 et seq.

90 For more on this issue see Dajczak, W. (2018) Op. cit., pp. 507-508.

91 DiMatteo, L.A. and Poncibò, C. (2018) Op. cit., pp. 815 et seq.; Werbach, K. and Cornell, N. (2017) Op. cit., pp. 318 et seq., 364.

92 Werbach, K. and Cornell, N. (2017) Op. cit., p. 377. Cf. DiMatteo, L.A. and Poncibò, C. (2018) Op. cit., p. 813.

93 Zimmermann, R. (1996) The Law of Obligations: Roman Foundations of the Civilian Tradition. Oxford: Oxford University Press, p. 578.

94 Cf. i.a.: Mik, E. (2017) Op. cit., p. 270; Gambino, A. (2017) Op. cit., pp. 13-14. On postulates regarding the introduction of human intervention in the model of smart contract operation, see i.a.: Allen, J.G. (2018) Op. cit., pp. 339-338, 341-342. On arguments claiming yet human impact on the smart contracts coding process, cf. i.a.: Grimmelmann, J. (2019) Op. cit., pp. 11 et seq., 21-23. 
Particular interdependencies individualised supra from the perspective of Polish law can be identified to an extent in regard to other legal systems, mainly those belonging to the continental legal tradition, ${ }^{95}$ given certain similarities among contract law frameworks in several aspects addressed within the scheme of the undertaken analysis. This is largely due to reception of essential Roman law principles relating to contractual

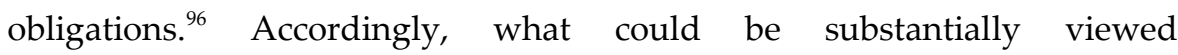
in a generalised manner as points of concern, are mainly the inconsistencies between the specificity of smart contracts and the methodology of contractual interpretation, the manner of determining the content of contractual obligation as well as the criteria of its due performance. Nonetheless, as already outlined, it is argued that a comparative overview of interpretative models and contract drafting techniques provides insight into why a higher degree of compatibility can be discerned between smart contracts model and common law framework than when confronted with the civil law one. ${ }^{97}$ Such an observation becomes all the more relevant as the influence of Anglo-American contract drafting style on both transnational and continental contractual practice is increasingly noticeable. $^{98}$

Innovative solutions arising from smart contracts infrastructure are only of limited application. ${ }^{99}$ The arguments that automated smart contracts will not constitute an alternative to traditional contracts, as they do not prove

95 By way of example, on detailed analysis undertaken recently as regards characteristics of smart contracts in the light of Swiss law of obligations, see: Carron, B. and Botteron, V. (2019) Op. cit. pp. 101-143; as regards German law context, cf. i.a.: Woebbeking, M.K. (2019) Op. cit., pp. 106-113; as regards some aspects of the French contract law framework, cf. i.a.: Cannarsa, M. (2018) Op. cit., pp. 779-780. Particular attention shall be drawn to Italian law because of the introduction of a definition of smart contracts at the legislative level (see i.a.: Pardolesi, R. and Davola, A. (2019) Op. cit., pp. 297-316; Donna, L. Di (2019) Diritto e tecnologia. Il contratto ai tempi dell'intelligenza artificiale e la giustizia predittiva. In: F. Capriglione (ed.). Liber Amicorum..., pp. 319 et seq.; Parola, L., Merati, P. and Gavotti, G. (2018) Op. cit., pp. 681-688).

96 Longchamps de Bérier, R. (1938) Op. cit., p. 3.

97 Cannarsa, M. (2018) Op. cit., pp. 776, 781-182. According to this view, what determines the above congruity is the apparent correspondence between the specificity of coding process characteristic for smart contracts and predominantly objective approach towards interpretation of contracts under common law which, in turn, is reflected in contracting parties' tendency towards drafting extensive contracts including any possible contingency so that it is possible to exclude unforeseeable judicial decisions. On current models of contractual interpretation from comparative legal perspective and interrelation between interpretative regimes and standards of contract drafting, see also i.a.: Kaczorowska, B. (2018a) Op. cit., pp. 263-264, 316 et seq., 468-473.

98 For more on this issue, see i.a.: Machnikowski, P., Balcarczyk, J. and Drela, M. (2017) Op. cit., pp. 42-43; Łolik, M. (2014) Op. cit., pp. 3-4; Strugała, R. (2013a) Op. cit., pp. 14-16; Strugała, R. (2013b) Op. cit., pp. 2-4, 7-11, 345-347.

99 Cf. DiMatteo, L.A. and Poncibò, C. (2018) Op. cit., pp. 813, 819-820, 823. 
capable of safeguarding the parties' interests across all types of legal relations, ${ }^{100}$ must be concurred with. It seems unquestionable that their implementation in practice shall not result in replacement of the existing legal framework nor annulment of contract law as such. What can be found suggestive is the call for a deeper analysis on the instances requiring the blockchain-based algorithmic constructs to be "combined" with human-interpreted legal institutions, based on an arguable assumption regarding the predisposition to coexist for both the smart contracts mechanism and contracts in a juridical sense. ${ }^{101}$ However, any eventual form of such interaction, assuming but ancillary role of technological innovations, shall warrant respect for principles of the objective moral order reflected in the private law system as well as compliance with key functions contract law is expected to perform. ${ }^{102}$ It appears appropriate to note that the debate on smart contracts from the legal perspective and the attempt to explore their impact on contractual practice contribute to accentuating the functionality and operability of the main contract law precepts. ${ }^{103}$

\section{LIST OF REFERENCES}

[1] Act of 23 April 1964 - Civil Code (ustawa - Kodeks cywilny, Journal of Laws of 2019 item 1145 , as amended).

[2] Allen, J.G. (2018) Wrapped and Stacked: 'Smart Contracts' and the Interaction of Natural and Formal Language. European Review of Contract Law, 14 (4).

[3] Bacina, M. (2018) When Two Worlds Collide: Smart Contracts and the Australian Legal System. Journal of Internet Law, 21 (8).

[4] Bierć, A. (2018) Zarys prawa prywatnego. Część ogólna. Warszawa: Wolters Kluwer.

[5] Bobrowicz, P. (2017) Psychologiczny kontekst oraz domniemania interpretacyjne i normy prawne w wykładni oświadczeń woli. Prawo i Więź, 3.

100 See: Szczerbowski, J.J. (2018a) Op. cit., p. 123. Cf. also: Szostek, D. (2019) Regulacje prawne drugiej dekady XXI wieku - dokąd zmierzamy? Czy zastąpi nas inżynieria prawa?. Monitor Prawniczy, 2, pp. 115, 118-119; Allen, J.G. (2018) Op. cit., p. 320; DiMatteo, L.A. and Poncibò, C. (2018) Op. cit., pp. 814, 823.

101 Cf. Werbach, K. (2018) Op. cit., pp. 534 et seq., 544 et seq. See also: Mik, E. (2018) Op. cit., pp. 855, 866, 870. On suggested implementation of hybrid "code-and-contract" combinations, assuming smart contracts being accompanied by traditional contracts, cf. Durovic, M. and Janssen, A. (2018) Op. cit., pp. 767-768, 770-771.

102 For more on main functions attributed to modern law of obligations, including the protective function, see i.a.: Radwański, Z. and Olejniczak, A. (2018) Op. cit., pp. 1-2.

${ }^{103}$ Cf. also: Werbach, K. and Cornell, N. (2017) Op. cit. , pp. 353 et seq., 374 et seq. 
[6] Brzozowski, A. (2013) Pojęcie umowy w prawie polskim, funkcje umów. Źródła prawa regulującego umowy. In: System prawa prywatnego. 5: E. Łętowska (ed.). Prawo zobowiązań - część ogólna. Warszawa: Wydawnictwo C.H. Beck.

[7] Brzozowski, A. (2014) Wpływ zmiany okoliczności na zobowiazania. Klauzula rebus sic stantibus. Warszawa: Wydawnictwo C.H. Beck.

[8] Brzozowski, A. (2018) Wpływ zmiany okoliczności na zobowiązania. In: System prawa prywatnego. 6: A. Olejniczak (ed.). Prawo zobowiazań- część ogólna. Warszawa: Wydawnictwo C.H. Beck.

[9] Cannarsa, M. (2018) Interpretation of Contracts and Smart Contracts: Smart Interpretation or Interpretation of Smart Contracts?. European Review of Private Law, $26(6)$.

[10] Caria, R. de. (2018) The Legal Meaning of Smart Contracts. European Review of Private Law, 26 (6).

[11] Carron, B. and Botteron, V. (2019) How Smart Can a Contract Be?. In: D. Kraus, T. Obrist and O. Hari (eds.). Blockchains, Smart Contracts, Decentralised Autonomous Organisations and the Law. Cheltenham-Northampton: Edward Elgar Publishing.

[12] Cieplak, J. and Leefatt, S. (2017) Smart Contracts: A Smart Way to Automate Performance. Georgetown Law Technology Review, 1 (2).

[13] Czepita, S. (2017) On the Concept of a Conventional Act and Its Types. Ruch Prawniczy, Ekonomiczny i Socjologiczny, 79 (1).

[14] Dajczak, W. (2012) The Nature of the Contract in Reasoning of Civilian Jurists. Poznan: Wydawnictwo Naukowe UAM.

[15] Dajczak, W. (2014) Kodeks zobowiązań jako lekcja metody prawnoporównawczej. Kwartalnik Prawa Prywatnego, 4.

[16] Dajczak, W. (2017) Amerykańska zapowiedź „śmierci umowy” na tle tradycji romanistycznej. In: F. Longchamps de Bérier (ed.). Dekodyfikacja prawa prywatnego. Szkice do portretu. Warszawa: Wydawnictwo Sejmowe.

[17] Dajczak, W. (2018) Zobowiązania. In: W. Dajczak, T. Giaro, F. Longchamps de Bérier. Prawo rzymskie. U podstaw prawa prywatnego. Warszawa: Wydawnictwo Naukowe PWN.

[18] Decree of the President of the Republic of Poland of 27 October 1933 - Code of Obligations (rozporządzenie Prezydenta Rzeczypospolitej- Kodeks zobowiązań, Journal of Laws No. 82, item 598, as amended).

[19] DiMatteo, L.A. and Poncibò, C. (2018) Quandary of Smart Contracts and Remedies: The Role of Contract Law and Self-Help Remedies. European Review of Private Law, 26 (6). 
[20] Donna, L. Di. (2019) Diritto e tecnologia. Il contratto ai tempi dell'intelligenza artificiale e la giustizia predittiva. In: F. Capriglione (ed.). Liber Amicorum Guido Alpa. Milano: Cedam.

[21] Druck, J.A. (2018) "Smart Contracts" Are Neither Smart Nor Contracts: Discuss. Banking \& Financial Services Policy Report, 37 (10).

[22] Durovic, M. and Janssen, A. (2018) The Formation of Blockchain-Based Smart Contracts in the Light of Contract Law. European Review of Private Law, 26 (6).

[23] Elizalde, F. de. (2018) The Sources and Effects of Contractual Terms: Towards Approximation of Common Law and Civil Law. In: F. de Elizalde (ed.). Uniform Rules for European Contract Law?: A Critical Assessment. Oxford: Hart Publishing.

[24] Gambino, A. (2017) Dignità umana e mercato digitale. Diritto Mercato Tecnologia.

[25] Geiregat, S. (2018) Cryptocurrencies Are (Smart) Contracts. Computer Law \& Security Review, 34 (5).

[26] Geis, G.S. (2008) Automating Contract Law. New York University Law Review, 83 (2).

[27] Giancaspro, M. (2017) Is a 'Smart Contract' Really a Smart Idea?: Insights from a Legal Perspective. Computer Law \& Security Review, 33 (6).

[28] Giaro, T. (2018) Kształtowanie i ochrona praw prywatnych. In: W. Dajczak, T. Giaro, F. Longchamps de Bérier. Prawo rzymskie. U podstaw prawa prywatnego. Warszawa: Wydawnictwo Naukowe PWN.

[29] Giaro, T. (2013) Some Prejudices about the Legal Tradition of Eastern Europe. In: B. Sitek, J.J. Szczerbowski and A.W. Bauknecht (eds.). Comparative Law in Eastern and Central Europe. Newcastle upon Tyne: Cambridge Scholars Publishing.

[30] Gnela, B. and Michałowska, K. (academic supervision). (2014) Directions of Private Law Development: Comments on the Draft of Book One of the Civil Code. Warszawa: Difin.

[31] Goldenfein, J. and Leiter, A. (2018) Legal Engineering on the Blockchain: 'Smart Contracts' as Legal Conduct. Law and Critique, 29 (2).

[32] Gorczyński, G. (2015) Klauzula rebus sic stantibus w XXI wieku. In: A. Olejniczak et al. (eds.). Wspótczesne problemy prawa zobowiazań. Warszawa: Lex a Wolters Kluwer Business.

[33] Governatori, G. et al. (2018) On Legal Contracts, Imperative and Declarative Smart Contracts, and Blockchain System. Artificial Intelligence and Law, 26 (4).

[34] Górska, K. (2018) Czynności prawne na tle innych zdarzeń cywilnoprawnych. In: E. Gniewek and P. Machnikowski (eds.). Zarys prawa cywilnego. Warszawa: Wydawnictwo C.H. Beck. 
[35] Graziadei, M. (2007) Variations on the Concept of Contract in a European Perspective. In: R. Schulze (ed.). New Features in Contract Law. Munich: Sellier European Law Publishers.

[36] Grimmelmann, J. (2019) All Smart Contracts Are Ambiguous. University of Pennsylvania Journal of Law and Innovation (forthcoming). [online] Available from: https://ssrn.com/ abstract=3315703 [Accessed 28 January 2019].

[37] Grundmann, S. and Hacker, P. (2017) Digital Technology as a Challenge to European Contract Law: From the Existing to the Future Architecture. European Review of Contract Law, 13 (3).

[38] Grykiel, J. (2018). In: M. Gutowski (ed.). Kodeks cywilny. 1: Komentarz. Art. 1-352. Warszawa: Wydawnictwo C.H. Beck.

[39] Hsiao, J.I.-H. (2017) Smart Contract on the Blockchain - Paradigm Shift for Contract Law?. US-China Law Review, 14 (10).

[40] Hulicki, M. and Lustofin, P. (2017) Wykorzystanie koncepcji blockchain w realizacji zobowiązań umownych. Człowiek w Cyberprzestrzeni, 1.

[41] Idelberger, F. (2018) Connected Contracts Reloaded - Smart Contracts as Contractual Networks. In: S. Grundmann (ed.). European Contract Law in the Digital Age. CambridgeAntwerp-Portland: Intersentia.

[42] Janas, A. (2018). In: M. Habdas and M. Fras (eds.). Kodeks cywilny. Komentarz. 1: Część ogólna (art. 1-125). Warszawa: Wolters Kluwer.

[43] Kaczorowska, B. (2018a) Wykładnia umów obligacyjnych w świetle współczesnych tendencji rozwoju prawa prywatnego. Wrocław: Wydawnictwo i Drukarnia Świętego Krzyża.

[44] Kaczorowska, B. (2018b) Zarys problematyki „prawa umów in statu renascendi”. In: A. Dańko-Roesler et al. (eds.). Ius est ars boni et aequi. Księga pamiątkowa dedykowana Profesorowi Józefowi Frąckowiakowi. Wrocław: Stowarzyszenie Notariuszy Rzeczypospolitej Polskiej.

[45] Kaczorowska, M. (2009) Rekodyfikacja prawa cywilnego w Polsce wobec rozwoju europejskiego prawa prywatnego. Rozważania na tle projektu księgi pierwszej Kodeksu cywilnego. Ruch Prawniczy, Ekonomiczny i Socjologiczny, 3.

[46] Kasprzyk, K. (2018) The Concept of Smart Contracts from the Legal Perspective. Review of Comparative Law, 34 (3).

[47] Klinger, B. and Szczepański, J. (2017) Blockchain - historia, cechy i główne obszary zastosowań. Człowiek w Cyberprzestrzeni, 1. 
[48] Kocot, W.J. (2017) Kontrakty kreatywne - nowy rozdział w cyberewolucji prawa umów. In: P. Kostański, P. Podrecki and T. Targosz (eds.). Experientia docet. Księga jubileuszowa ofiarowana Pani Profesor Elżbiecie Traple. Warszawa: Wolters Kluwer.

[49] Kolber, A.J. (2018) Not-So-Smart Blockchain Contracts and Artificial Responsibility. Stanford Technology Law Review, 21 (2).

[50] Komisja Kodyfikacyjna Prawa Cywilnego działająca przy Ministrze Sprawiedliwości. (2009) Ksiega pierwsza Kodeksu cywilnego. Projekt zuzasadnieniem. Warszawa: Wydawnictwo C.H. Beck.

[51] Konopacka, M. (2017) Kamienie milowe w rozwoju historycznym polskiego prawa umów. Gdańskie Studia Prawnicze, 38 (2).

[52] Kurosz, K. (2017) Zawieranie umów przez sztuczną inteligencję (systemy autonomiczne) a wady oświadczeń woli - wprowadzenie do problemu. In: W. Robaczyński (ed.). Czynić postęp wprawie. Księga jubileuszowa dedykowana Profesor Birucie Lewaszkiewicz-Petrykowskiej. Łódź: Wydawnictwo Uniwersytetu Łódzkiego.

[53] Levy, K.E.C. (2017) Book-Smart, Not Street-Smart: Blockchain-Based Smart Contracts and The Social Workings of Law. Engaging Science, Technology, and Society, 3.

[54] Longchamps de Bérier, F. (2016) Z uwag do metodologii nauki prawa prywatnego: argumenty historyczny, dogmatyczny i prawnoporównawczy na przykładzie darowizny na wypadek śmierci oraz zapisu windykacyjnego. In: A. Wudarski (ed.). Polska komparatystyka prawa. Prawo obce w doktrynie prawa polskiego. Warszawa: Stowarzyszenie Notariuszy Rzeczypospolitej Polskiej.

[55] Longchamps de Bérier, F. (2019) Decodification of Contract Law. In: C. Su, F. Longchamps de Bérier and P. Grzebyk (eds.). Theory and Practice of Codification: The Chinese and Polish Perspectives. Beijing: Social Sciences Academic Press.

[56] Longchamps de Bérier, R. (1938) Zobowiązania. Lwów: Księgarnia Wydaw. Gubrynowicz i Syn.

[57] Łolik, M. (2014) Wspótczesne prawo kontraktów- wybrane zagadnienia. Warszawa: Wydawnictwo C.H. Beck.

[58] Machnikowski, P. (2010) Prawne instrumenty ochrony zaufania przy zawieraniu umowy. Wrocław: Wydawnictwo Uniwersytetu Wrocławskiego.

[59] Machnikowski, P. (2013a) Struktura zobowiązania. In: System prawa prywatnego. 5: E. Łętowska (ed.). Prawo zobowiązań - część ogólna. Warszawa: Wydawnictwo C.H. Beck.

[60] Machnikowski, P. (2013b) Swoboda umów. In: System prawa prywatnego. 5: E. Łętowska (ed.). Prawo zobowiązań - część ogólna. Warszawa: Wydawnictwo C.H. Beck. 
[61] Machnikowski, P. (2013c) Treść umowy. In: System prawa prywatnego. 5: E. Łętowska (ed.). Prawo zobowiązań - część ogólna. Warszawa: Wydawnictwo C.H. Beck.

[62] Machnikowski, P. (2014) Poland. In: J. Hurdík, P. Lavický et al. (eds.). Private Law Reform. Brno: Masaryk University.

[63] Machnikowski, P. (2015a) Merger Clause in Contracts under Polish Law. In: B. Gessel-Kalinowska vel Kalisz (ed.). The Challenges and the Future of Commercial and Investment Arbitration: Liber Amicorum Professor Jerzy Rajski. Warsaw: Lewiatan Court of Arbitration.

[64] Machnikowski, P. (2015b) Prawo zobowiązań w 2025 roku. Nowe technologie, nowe wyzwania. In: A. Olejniczak et al. (eds.). Wspótczesne problemy prawa zobowiązań. Warszawa: Lex a Wolters Kluwer Business.

[65] Machnikowski, P. (2017a). In: E. Gniewek and P. Machnikowski (eds.). Kodeks cywilny. Komentarz. Warszawa: Wydawnictwo C.H. Beck.

[66] Machnikowski, P. (2017b). In: P. Machnikowski (ed.). Kodeks cywilny. Księga pierwsza. Część ogólna. Projekt Komisji Kodyfikacyjnej Prawa Cywilnego przyjęty w 2015 r. z komentarzem członków Zespołu Problemowego KKPC. Warszawa: Wydawnictwo C.H. Beck.

[67] Machnikowski, P., Balcarczyk, J. and Drela, M. (2017) Contract Law in Poland. Alphen aan den Rijn: Kluwer Law International.

[68] Malby, S. (2017) Strengthening the Rule of Law through Technology. Commonwealth Law Bulletin, 43 (3-4).

[69] Mańko, R. (2016) Towards a Typology of Dimensions of the Continuity and Discontinuity of Law: The Perspective of Polish Private Law after the 1989 Transformation. Wroclaw Review of Law, Administration and Economics, 6 (2).

[70] Mik, E. (2017) Smart Contracts: Terminology, Technical Limitations and Real World Complexity. Law, Innovation and Technology, 9 (2).

[71] Mik, E. (2018) Electronic Platforms: Openness, Transparency \& Privacy Issues. European Review of Private Law, 26 (6).

[72] Millard, C. (2018) Blockchain and Law: Incompatible Codes? Computer Law E Security Review, 34 (4).

[73] Ministerstwo Cyfryzacji. (2019) Grupa robocza ds. rejestrów rozproszonych $i$ blockchain. [online] Available from: https://www.gov.pl/web/cyfryzacja/grupa-robocza-ds-rejestrow -rozproszonych-i-blockchain1 [Accessed 7 August 2019]. 
[74] Pardolesi, R. and Davola, A. (2019) "Smart contract": lusinghe ed equivoci dell'innovazione purchesia. In: F. Capriglione (ed.). Liber Amicorum Guido Alpa. Milano: Cedam.

[75] Parola, L., Merati, P. and Gavotti, G. (2018) Blockchain e smart contract: questioni giuridiche aperte. I Contratti, 6.

[76] Pecyna, M. (2013) Merger clause jako zastrzeżenie wyłaczności dokumentu, klauzula integralności umowy, reguła wykładni umowy. Warszawa: Lex a Wolters Kluwer Business.

[77] Piaskowy, A. (2012) Klauzule generalne w projekcie nowego kodeksu cywilnego. Transformacje Prawa Prywatnego, 3.

[78] Polański, P. (2019) Inwigilacja, dostępność, blockchain i sztuczna inteligencja: pytania o kierunki rozwoju prawa nowych technologii w erze rewolucji internetowej. Monitor Prawniczy, 2.

[79] Radwański, Z. and Mularski, K. (2019a) Wykładnia oświadczeń woli. In: A. Olejniczak and Z. Radwański (eds.). System prawa prywatnego. 2: Prawo cywilne-część ogólna. Warszawa: Wydawnictwo C.H. Beck.

[80] Radwański, Z. and Mularski, K. (2019b) Zagadnienia ogólne czynności prawnych. In: A. Olejniczak and Z. Radwański (eds.). System prawa prywatnego. 2: Prawo cywilneczęść ogólna. Warszawa: Wydawnictwo C.H. Beck.

[81] Radwański, Z. and Olejniczak, A. (2017) Prawo cywilne-część ogólna. Warszawa: Wydawnictwo C.H. Beck.

[82] Radwański, Z. and Olejniczak, A. (2018) Zobowiazania- czesść ogólna. Warszawa: Wydawnictwo C.H. Beck.

[83] Raskin, M. (2017) The Law and Legality of Smart Contracts. Georgetown Law Technology Review, 1 (2).

[84] Reyes, C.L. (2018) Cryptolaw for Distributed Ledger Technologies: A Jurisprudential Framework. Jurimetrics: The Journal of Law, Science \& Technology, 58 (3).

[85] Ridder, C.A. de, Tunstall, M.K. and Prescott, N. (2017) Recognition of Smart Contracts in the United States. Intellectual Property \& Technology Law Journal, 29 (11).

[86] Rodrigues, U.R. (2019) Law and the Blockchain. Iowa Law Review, 1014 (2).

[87] Rohr, J. (2019) Smart Contracts in Traditional Contract Law, Or: The Law of the Vending Machine. Cleveland State Law Review, 67 (1).

[88] Romanowski, M. (2013) Position of the Law of Obligations in Polish Law in the Context of a Reform of the European Law of Obligations. In: R. Schulze and F. Zoll (eds.). 
The Law of Obligations in Europe: A New Wave of Codifications. Munich: Sellier European Law Publishers.

[89] Rott-Pietrzyk, E. (2010) Klauzule generalne a wykonanie zobowiązania (z uwzględnieniem koncepcji systemu klauzul generalnych w projekcie kc). In: E. Gniewek, K. Górska and P. Machnikowski (eds.). Zaciaganie i wykonywanie zobowiązań. Materiały III Ogólnopolskiego Zjazdu Cywilistów (Wrocław, 25-27.9.2008 r.). Warszawa: Wydawnictwo C.H. Beck.

[90] Rott-Pietrzyk, E. (2013) Interpretacja umów w prawie modelowym i wspólnym europejskim prawie sprzedaży (CESL). Warszawa: Wydawnictwo C.H. Beck.

[91] Rudnicki, J. (2018) Dekodyfikacja prawa cywilnego w Polsce. Bielsko-Biała: Wydawnictwo Od.Nowa.

[92] Samolewicz, S. (1937) Zarys polskiego prawa zobowiązań. Lwów: Skł. gł. Księgarnia T.S.L.

[93] Savelyev, A. (2017) Contract Law 2.0: 'Smart' Contracts as the Beginning of the End of Classic Contract Law. Information \& Communications Technology Law, 26 (2).

[94] Scholz, L.H. (2017) Algorythmic Contracts. Stanford Technology Law Review, 20 (2).

[95] Schulze, R. and Staudenmayer, D. (2016) Digital Revolution - Challenges for Contract Law. In: R. Schulze and D. Staudenmayer (eds.). Digital Revolution: Challenges for Contract Law in Practice. Baden-Baden: Nomos.

[96] Sellwood, M. (2017) The Road to Autonomy. San Diego Law Review, 54 (4).

[97] Sklaroff, J.M. (2017) Smart Contracts and the Cost of Inflexibility. University of Pennsylvania Law Review, 166 (1).

[98] Sobolewski, P. (2017). In: K. Osajda (ed.). Kodeks cywilny. Komentarz. 1: Część ogólna. Przepisy wprowadzające kc. Prawo onotariacie (art.78-95 i96-99). Warszawa: Wydawnictwo C.H. Beck.

[99] Strugała, R. (2013a) Merger Clauses in Contracts Governed by Polish Law. Wroclaw Review of Law, Administration and Economics, 3 (1).

[100] Strugała, R. (2013b) Standardowe klauzule umowne: adaptacyjne, salwatoryjne, merger, interpretacyjne oraz pactum de forma. Warszawa: Wydawnictwo C.H. Beck.

[101] Szczerbowski, J.J. (2018a) Lex cryptographia. Znaczenie prawne umów ijednostek rozliczeniowych opartych na technologii blockchain. Warszawa: Wydawnictwo Naukowe PWN.

[102] Szczerbowski, J.J. (2018b) Transaction Costs of Blockchain Smart Contracts. Law and Forensic Science, 16 (2).

[103] Szostek, D. (2018) Blockchain a prawo. Warszawa: Wydawnictwo C.H. Beck. 
[104] Szostek, D. (2019) Regulacje prawne drugiej dekady XXI wieku - dokąd zmierzamy? Czy zastąpi nas inżynieria prawa?. Monitor Prawniczy, 2.

[105] Temte, M.N. (2019) Blockchain Challenges Traditional Contract Law: Just How Smart Are Smart Contracts?. Wyoming Law Review, 19 (1).

[106] The Civil Code. Kodeks cywilny (2019). E. Kucharska (transl.). Warszawa: Wydawnictwo C.H. Beck.

[107] Werbach, K. (2018) Trust, but Verify: Why the Blockchain Needs the Law. Berkeley Technology Law Journal, 33 (2).

[108] Werbach, K. and Cornell, N. (2017) Contracts Ex Machina. Duke Law Journal, 67 (2).

[109] Wheeler, S. (2017) Visions of Contract. Journal of Law and Society, 44 (S1).

[110] Wilejczyk, M. (2014) Zagadnienia etyczne części ogólnej prawa prywatnego. Warszawa: Wydawnictwo C.H. Beck.

[111] Włodyka, S. and Spyra, M. (2017) Ogólna charakterystyka umów handlowych. In: M. Stec (ed.). System prawa handlowego. 5: Prawo umów handlowych, Warszawa: Wydawnictwo C.H. Beck.

[112] Woebbeking, M.K. (2019) The Impact of Smart Contracts on Traditional Concepts of Contract Law. Journal of Intellectual Property, Information Technology and E-Commerce Law, $10(1)$.

[113] Zagrobelny, K. (2018a) Umowy jako źródło zobowiązań. In: E. Gniewek and P. Machnikowski (eds.). Zarys prawa cywilnego. Warszawa: Wydawnictwo C.H. Beck.

[114] Zagrobelny, K. (2018b) Wykonanie zobowiązania, In: E. Gniewek and P. Machnikowski (eds.). Zarys prawa cywilnego. Warszawa: Wydawnictwo C.H. Beck.

[115] Zimmermann, R. (1996) The Law of Obligations: Roman Foundations of the Civilian Tradition. Oxford: Oxford University Press.

[116] Zweigert, K. and Kötz, H. (2011) Introduction to Comparative Law. transl. T. Weir. Oxford: Clarendon Press. 